\title{
Leveraging material efficiency as an energy and climate instrument for heavy industries in the EU
}

Ana Gonzalez Hernandez ${ }^{a}$, Simone Cooper-Searle ${ }^{b}$, Alexandra C. H. Skelton ${ }^{a}$, Jonathan M. Cullen ${ }^{a}$.

${ }^{a}$ Dept. of Engineering, University of Cambridge, Trumpington St., Cambridge CB2 1PZ, UK

${ }^{b}$ Sustainable Resource Economy, Chatham house - Royal institute of International Affairs, $U K$ 


\begin{abstract}
Material efficiency is indispensable to reaching agreed targets for industry's energy and carbon emissions. Yet, in the EU, the energy- and emissions-saving potentials of this strategy continue to be framed as secondary outcomes of resource-related policies. Understanding why material efficiency has been overlooked as an energy/climate solution is a prerequisite for proposing ways of changing its framing, but existing studies have failed to do so. This paper fills this gap by triangulating interviews, policy documents and three policy theories: namely, historical and rational choice institutionalism, and multiple streams framework. Factors discouraging material efficiency as an energy and climate strategy include: difficulties in reframing the prevailing rationale to pursue it; the inadequacy of monitored indicators; the lack of high-level political buy-in from DG Energy and Clima; the ETS policy lock-in; uncoordinated policy management across Directorates; the lack of a designated industry lobby. Policy solutions are proposed. Before 2030, these are limited to minor amendments, e.g. guidance on embodied energy calculations or industry standards. Post-2030, more radical interventions are possible, such as introducing new fiscal drivers, re-designing the ETS emissions cap or benchmarks for allowances. This evidence suggests that the transition to a low-carbon industry will require Member State- and industry-level action.

Keywords: Material efficiency; energy and climate policies; multiple stream framework; new institutionalism; rational choice institutionalism; resource efficiency.

\begin{tabular}{llll}
\hline Nomenclature & & & \\
\hline Abbreviations & & & \\
BREF & Best Practice Reference document & GhG & Greenhouse Gas \\
CE & Circular Economy & HI & Historical Institutionalism \\
DG & Directorate General & IED & Industrial Emissions Directive \\
EC & European Commission & JRC & Joint Research Center \\
EE & Energy Efficiency & LCA & Life-cycle Assessment \\
EEA & European Environment Agency & ME & Material Efficiency \\
EED & Energy Efficiency Directive & MSF & Multiple Streams Framework \\
ETS & Emissions Trading Scheme & RCI & Rational Choice Institutionalism \\
EU & European Union & RE & Resource Efficiency \\
\hline
\end{tabular}
\end{abstract}

\title{
1 Material efficiency: a tool to reduce energy use in heavy industries
}

In 2016, industry was responsible for over a quarter of the European Union's (EU) total final energy use (Eurostat, 2018), and just under half of this was consumed in energy-intensive industries. Improving energy efficiency (EE) in these industries is therefore key to reduce carbon dioxide $\left(\mathrm{CO}_{2}\right)$ emissions and energy demand (EC (2016b)) in the region. Yet potential gains from $\mathrm{EE}$ have proved to be limited compared to the scale of $\mathrm{CO}_{2}$ emissions reduction targets (Allwood et al. (2010); Fischedick et al. (2014)).

There is a growing body of academic literature which contends that reducing the use of energy- 
intensive materials through material efficiency $(\mathrm{ME})^{1}$ - using less materials to provide the same service - could be a complementary strategy to address the emissions gap. Allwood et al. (2011) propose nine strategies to improve ME: light-weighting, re-using, re-manufacturing, recycling, diverting scrap, extending product lives, using products more intensely, improving process yields, and substituting materials. Several studies have quantified the technical potential for improvement of some of these strategies in energy-intensive sectors, e.g. steel (Allwood and Cullen (2012); Milford et al. (2013); Pauliuk and Müller (2014)), aluminium (Cullen and Allwood (2013)), paper (Griffin et al. (2018); Van Ewijk et al. (2017)), cement (Kajaste and Hurme (2016)) and chemicals (Griffin et al. (2017)). Overall, Cooper et al. (2017b) estimate that $6-11 \%$ of the energy used to support economic activity, both globally and in the EU, can be saved by improving ME. In steelmaking, Cullen et al. (2012) reveal that over a quarter of the global liquid steel produced is lost in casting (74 Mt), forming (99 Mt) and fabrication (186 Mt).

ME also has proponents outside of academia, with interest from the International Energy Agency (IEA, 2015), Intergovernmental Panel on Climate Change (Fischedick et al. (2014)) and United Nations Environmental Programme (Etkins and Hughes (2017)). All three signal it is an under-explored $\mathrm{CO}_{2}$ mitigation strategy which merits further policy attention.

In the European Commission (EC), policies that support ME belong within the environmental policy remit (EC (2011a)) - in the Directorate General (DG) for Environment - rather than energy and climate. These environmental policies aim to guarantee resource availability, reduce price volatility and drive economic growth (EEA (2010, 2016); EC (2011b)), framing impacts on energy use and emissions as potential secondary outcomes. Industrial policies aimed at reducing energy and emissions, however, have yet to leverage ME as a tool to achieve the region's binding energy and emissions targets. In fact, Skelton and Allwood (2017) and Neuhoff et al. (2016) have showed that the Emissions Trading Scheme (ETS) - the EU's main climate policy - provides inadequate incentives for material efficiency.

This paper sets out to answer two research questions:

1. Why is material efficiency not part of the EU's energy and climate policy remit?

2. How could it become a policy option to help reduce energy and emissions?

\section{Review}

Answering these questions requires: an understanding of the current EU energy, climate and resource policies (Section 2.1); an assessment of existing studies that investigate the prominence, or otherwise, of ME in these policy areas (Section 2.2); and a review of frameworks that examine the agenda-setting process (Section 2.3). Together, these three strands of literature inform the research approach to this study (Section 2.4).

\footnotetext{
${ }^{1}$ The terms ME and resource efficiency (RE) are often used interchangeably. Here, the term ME denotes the strategies identified by Allwood et al. (2011), as well as industrial symbiosis - the recovery of by-products.
} 


\subsection{The EU's energy, climate and resource-related policies}

The EC has a breadth of policy tools at hand to incentivise and enforce the reduction of energy and material use (the combination of which we denote as 'resources') in heavy industries. Currently, four main policy areas can influence this: (1) the Energy Union; (2) DG Energy (EC (2006, 2011b, 2014d)); (3) DG Environment (EC, 2011a, 2014c); and (4) DG Clima. ${ }^{2}$ Figure 1 uses the policy pyramid approach (Reinaud and Goldberg (2011)) to characterise the EU policy landscape shaping resource use in industry. Policies are divided into three groups: effort-defining policies; supporting measures that encourage the delivery of these efforts; implementation tools that help operationalise these ${ }^{3}$. See Table A.1 for more details.

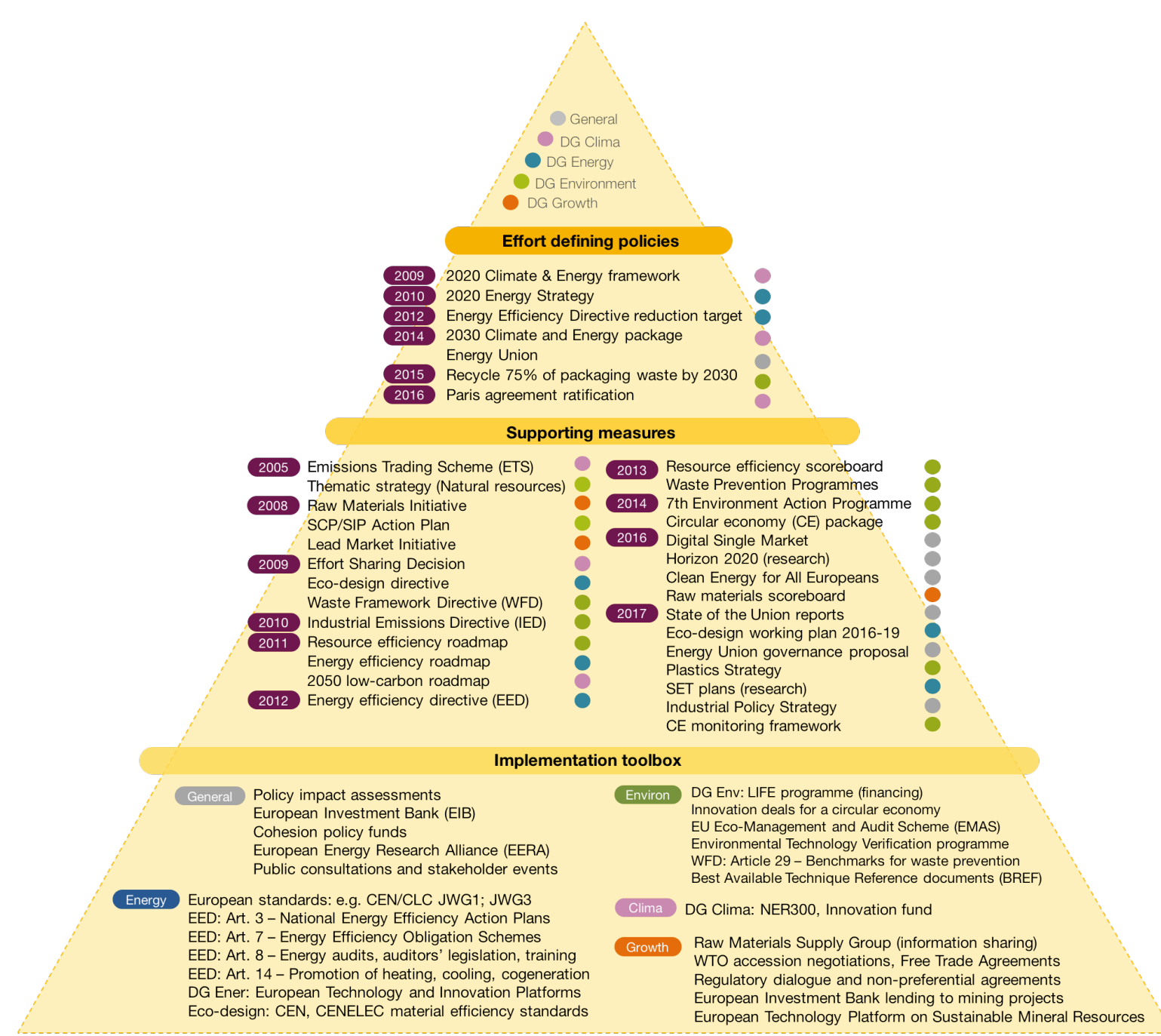

Figure 1: Pyramid for EU's climate, environment and energy policies related to energy-intensive industries. Colours indicate the policy area in charge of the given policy.

Starting at the top of the pyramid, there are three effort-defining policies for heavy industries,

\footnotetext{
${ }^{2}$ Aside from these, DG Growth and other Commission-wide initiatives can occasionally indirectly impact industrial energy and material use (as shown in Figure 1 and 2).

${ }^{3}$ We exclude two policies Circle Economy (2017): Extended Producer Responsibility (EPR) and Green Public Procurement (GPP). The former, although effective in areas such as batteries, electric vehicles and packaging, is not particularly relevant to heavy industries. Similarly, GPP only has an indirect impact.
} 
all motivated by the need to reduce energy and emissions: the 2020 climate and energy package; the 2030 climate and energy framework (EC (2008a, 2014a)); the Energy Union. These impose two economy-wide targets for 2020 and 2030; one on emissions (20\% and 40\% reduction) and one on energy use ( $20 \%$ and $27 \%$ reduction).

The ETS is the main supporting measure for these effort-defining policies (EC (2009a)). Other regulatory mechanisms that provide tangible support include the: (1) Eco-design directive, which targets energy-consuming devices; (2) Energy Efficiency Directive (EED), which enforces energy auditing in large enterprises (Article 8); (3) IED, which defines best available techniques for installation permits (EC (2009b)); (4) the Raw Materials Initiative, which aims to improve the market for secondary materials (EC (2008c)); (5) waste legislation, which is now under the Circular Economy (CE) package (EC (2015b)). The remaining supporting measures mainly provide the foundations from which longer-term progress can be initiated: roadmaps, monitoring frameworks and research funding, e.g. Horizon 2020.

At the bottom of the pyramid, a number of implementation instruments are available, which enable engagement with the wider policy community. For example: training programmes, stakeholder platforms, regulation guidelines, impact assessments and public consultations.

Visualising the coverage of the most relevant ME measures across existing EU policies - portrayed in Figure 2 - reveals that only a subset of these are currently covered by DG Environment, with little support offered for measures such as light-weighting or yield improvements. Policies targeted at industrial energy use primarily focus on heating, cooling, recovering waste heat, and fuel switching. The EU's flagship climate policy, the ETS, provides weak incentives to introduce any ME strategies (Skelton and Allwood (2017); Aidt et al. (2017); Neuhoff et al. (2016)), and IED's guidelines on best practice do not explicitly cover $\mathrm{ME}$ and target non- $\mathrm{CO}_{2}$ emissions ${ }^{4}$.

\subsection{Analyses of EU-level material efficiency policies}

Section 2.1 shows that ME cuts across multiple Directorates and policy objectives and the literature examining ME-related policies is similarly diverse. The reviewed studies, summarised in Table 1, can be grouped into four categories, those which investigate: (1) the suitability of ME indicators; (2) the barriers to ME; (3) the analysis of policy agendas; (4) options for and impacts of policy interventions. From these, the most relevant papers are highlighted with asterisks $\left(^{*}\right)$ in Table 1.

Mehlhart et al. (2016) investigated the, as yet, under-explored energy-saving potential of ME as an option to achieve energy targets. The report identifies barriers only for a subset of ME measures in different sectors, including heavy industry, and proposes remedial interventions. Similarly, Scott et al. (2017) analyse ways in which EU product policies could be extended to include aspects on material and product use; they propose modifying these to include

\footnotetext{
${ }^{4}$ They only cover the production facility, limiting the extent to which they can regulate upstream environmental impacts and outgoing material streams - where gaps for ME improvements lie (EPA (2016))
} 


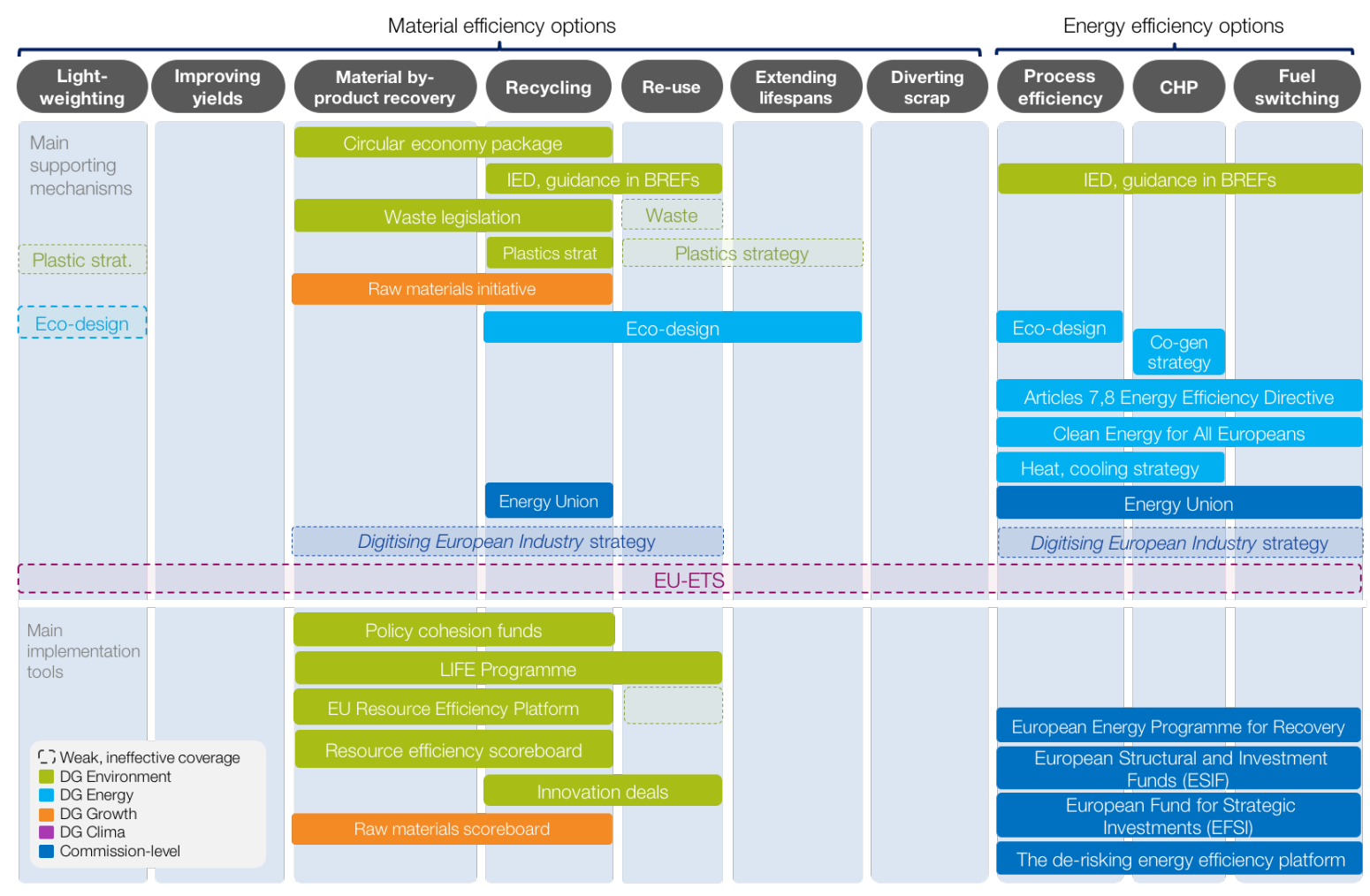

Figure 2: Non-exhaustive overview of policies currently influencing or covering ME and EE; Plastic strat. (Plastic strategy).

embodied emissions - currently unaddressed by the ETS. Yet, Mehlhart et al. (2016), do not consider the complete policy landscape shown in Figure 1, and Scott et al. (2017) provide no empirical evidence. Neither study investigates the lack of attention given to ME in energy/climate policies, but rather take this as their starting point.

Two studies examine the economic rationale for policies that incentivise ME in industry. Neuhoff et al. (2016) and Skelton and Allwood (2017) specifically analysed the potential role of the ETS in stimulating ME. Neuhoff et al. (2016) propose the inclusion of a consumption charge, and Skelton and Allwood (2017) suggest the removal of distortive taxes and the implementation of carbon leakage exemptions that "are independent of embodied carbon". Despite valuable analyses, they, again, fail to reference the broader policy landscape, and provide limited insight into the political and behavioural aspects taking part.

Cooper-Searle et al. (2017) use the Multiple Streams Framework (MSF) from Kingdon (1984) to investigate why ME is not a bigger part of the UK climate policy agenda. The authors go beyond quantitative economic analyses, and provide meaningful insights into the aspects influencing policymakers' decisions. Yet, restricted to the UK's automotive sector, it provides limited insight into the agenda-setting process for climate strategies at EU-level.

The EU is committed to reduce energy use by $20 \%$ before 2020 and by at least $27 \%$ before 2030. The successful adoption of ME in heavy industries is key in achieving these. None of the studies in the literature investigates why the EU's energy and climate policies continue to under-leverage this. Yet, understanding why an issue has been overlooked by policymakers 


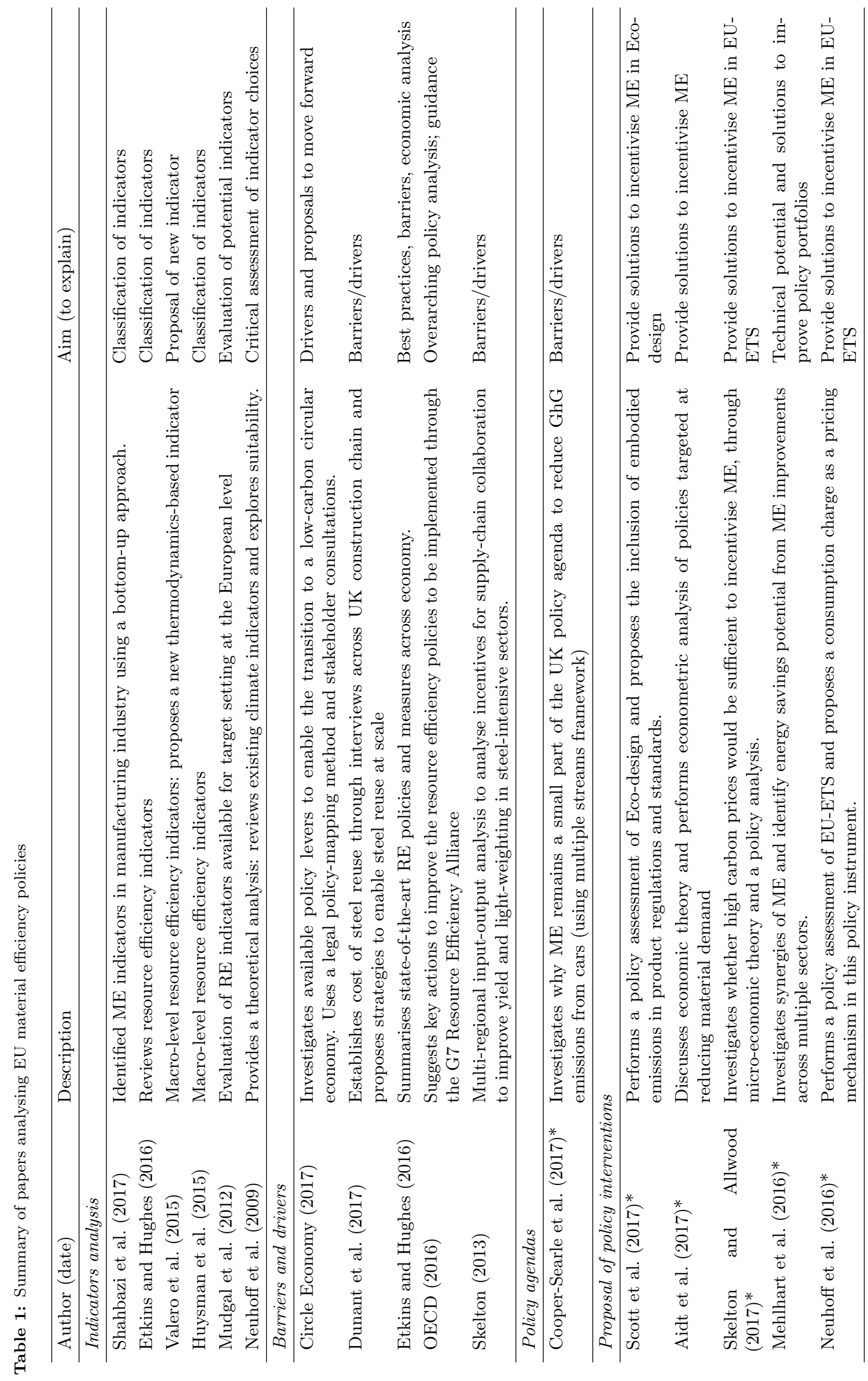


is a prerequisite for proposing ways of changing this.

\subsection{Public policy theories: explaining the agenda-setting process}

The complexity of policy formation has resulted in a rich volume of conceptual frameworks or theories that seek to explain why specific issues do or do not become part of specific policy agendas. These provide researchers with a simplified yet systematic method through which to understand behavioural, institutional and political factors affecting the agenda-setting process. This section reviews three policy frameworks that are appropriate to analyse the inclusion, or omission, of a technical solution such as ME, in the EU's energy and climate agenda. These are: Rational Choice Institutionalism (RCI), New Institutionalism, and the Multiple Stream Framework (MSF).

Borrowing from neo-classical economics, Rational Choice Institutionalism assumes that individuals are homogeneous rational actors who compare expected benefits and costs of their actions prior to adoption (Hindess (1984); Ostrom (1991)) and whose choices are constrained by institutions. In the EU, RCI has provided the theoretical foundations for other theories of the policy process, such as the 'transaction-cost approach (Huber and Shipan (2003)), and has served as a means of formulating formal macro-economic models (Pollack (2006)).

This simplistic portrayal of the policy process and its actors, however, puts "politics in service of the economy" (Meadwell (2005)) and fails to capture the complexity of actors motivations, their decision-making process and the reconciliation of policy trade-offs seen in practice (Norgaard (1996)). Lindblom (1959) has long criticised RCI for its inability to explain incremental policy changes. Pollack (2006) concludes that RCI has limited applicability; it is most valuable when individual's decisions are most relevant, where there is sufficient internal expertise, and where institutional structures and rules are clearly defined.

This has prompted modifications to the original theory - often categorised under the rubric of "new institutionalism" - by expanding on the motivations of actors, the mechanisms of policy change and the relevance of historical developments. Among these, two prominent theories have received most academic attention: (1) historical institutionalism (HI), which focuses on understanding the relevance of path dependency in new policy developments (e.g. Pedersen (2017); Mahoney (2000)); (2) sociological institutionalism, which posits institutions are shaped by culture, experience and behaviour instead of rationality (e.g. Axford (2015); Lombardo and Forest (2015)).

Other new-institutionalist theories investigated the effect of institutions on the interactions between actors. For example, to explain the relationships between EU policymakers, Princen and Rhinard (2006) - based on Cobb (1976) - proposed two types of institutional dynamics: high politics, where issues become part of an agenda from top-down political interventions; and low politics, where an issue is raised by junior members. The rationale for making this distinction is that the two routes have different features (see Table A.3). 
MSF developed by Kingdon (1984), incorporates exogenous factors that remain unexplored in institutionalist theories. Based on bounded rationality, this theory characterises the transience of opportunities available to bring problems to the attention of policymakers. Although originally informed by US policy developments, MSF has universal applicability and has been applied to understand EU agenda-setting process (see examples in Table A.4). MSF has two main advantages: it explicitly considers the characteristics of policy solutions; it does not rely on an understanding of policy processes over long time periods (Sabatier et al. (1999)), which is beneficial for the study of ME, a relatively new topic. Yet, as argued by Brunner (2008), MSF is less appropriate for capturing institutional and behavioural aspects.

This literature reveals that no single theory can capture all the factors influencing whether specific policy issues are included or omitted from policy agendas. In fact, Cairney (2007) contends that studies relying on several frameworks provide more complete explanations of policy change and its drivers, especially if these studies "do not seek confirm the value of one particular model". We therefore posit that a combination of theories is needed to assess why $\mathrm{ME}$ is not part of the energy and climate agendas; the exact combination of which will be determined from the evidence collected.

\subsection{Research proposal}

This section confirms that a comprehensive explanation of why ME is omitted from energy and climate agendas in the EU - where the entire gamut of EU energy, climate and resource policies is considered - is missing. It also shows that a combination of policy frameworks is likely to provide the richest explanation of why this is the case. Based on this, we seek to provide two contributions to knowledge. First, to explain why ME is yet to become part of the energy and climate agendas by investigating all relevant policy areas that could promote ME in heavy industry. Second, to explore interventions through which to integrate ME in energy and climate strategies, and thereby to contribute to the discussion on how to facilitate the transition to a low-carbon heavy industry.

\section{Method}

Figure 3 portrays a schematic explaining the method used to collect and analyse the evidence. The rest of the section outlines how a combination of frameworks are applied to our study, expanding on the literature described in Section 2.3 and the empirical data collected.

Rather than rigidly adhering to a particular policy lens, our results are structured based on a combination of conceptual frameworks focused on agenda-setting - MSF, HI and RCI (Cairney and Jones (2016); Kingdon (1984); Sabatier et al. (1999); Gottweis (2007)). The content of these results is founded on evidence from policy documents (Section 3.2) and semi-structured interviews (Section 3.3). These two data sources were manually coded and combined to provide a more comprehensive overview of the variables affecting the integration of ME in energy/climate policies. 


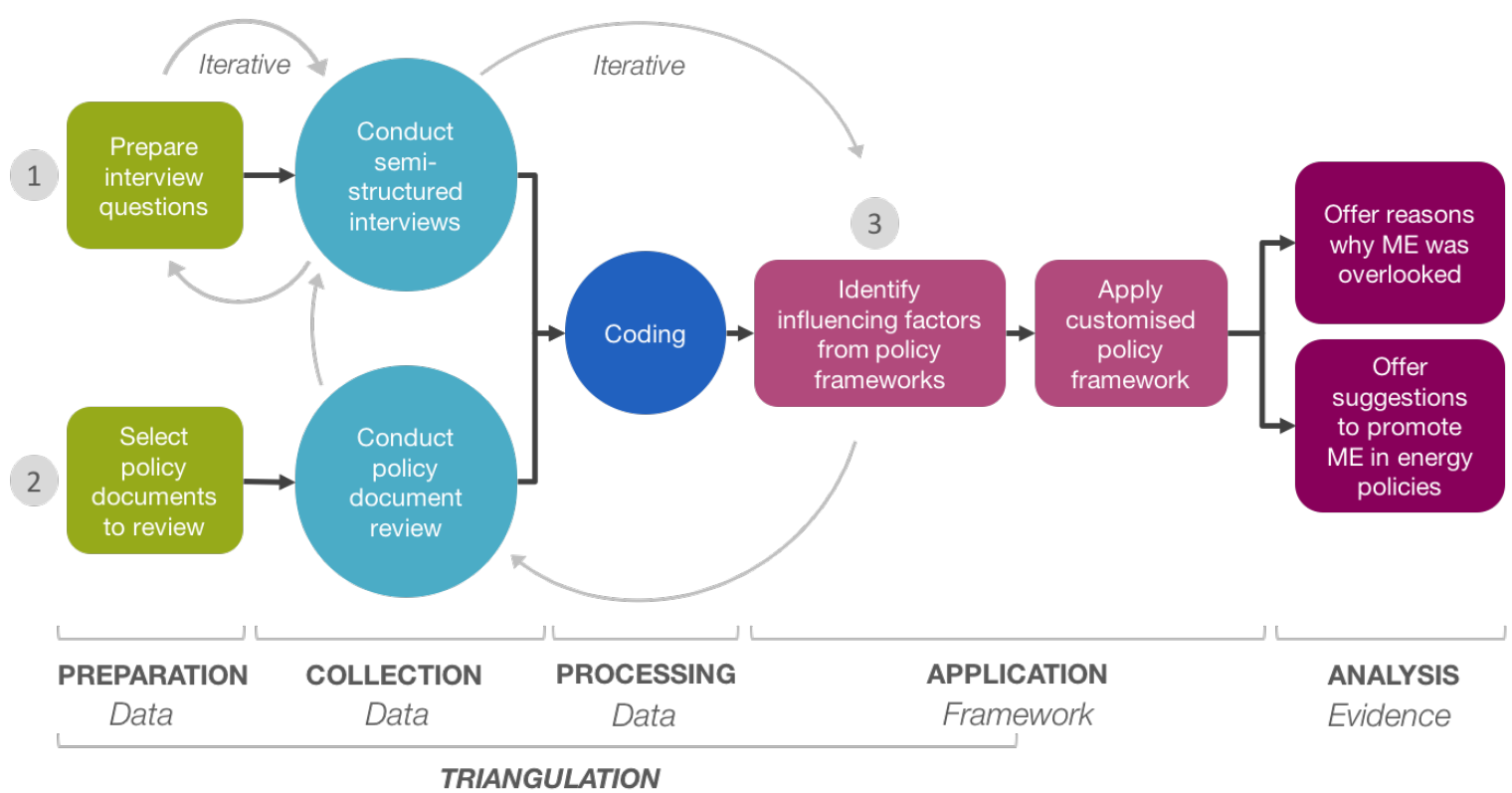

Figure 3: Overview of method used to analyse the setting of the EU policy agenda

Studies on the EU's agenda-setting process often take a neo-functionalist approach and consider the Commission as the main decision-maker (Herweg (2016); Richardson (2001); Zahariadis (2008)) - even if this represents just one of the multiple relevant EU institutions. This analysis follows this assumption, and is based around EU- rather than the Memberstate-level agendas, with a specific focus on the Commission.

\subsection{Defining the conceptual framework}

As part of the manual coding process, interviews and policy documents were triangulated with policy-theory literature to identify the variables influencing policymakers' decisions. These were structured into three sections (Figure 4): problem perception, institutional and political factors, and solution readiness. The following paragraphs describe each of these sections in turn. Table 2 details why the specific variables in Figure 4 were included and on how these influential factors were modified from their respective original frameworks.

Problem perception is assessed first. This, borrowing from Kingdon's problem stream (Kingdon (2003, 1984)), includes evaluating the evidence pertaining to: (1) how ME solutions are understood among the policy community; (2) the indicators used to track progress on EE, RE and emissions; and (3) events that may have sparked the attention of policymakers working in these areas.

The influence of institutional and political factors is examined next. This section combines variables from Kingdon's political stream and the institutionalist approaches - both Historical and Rational Choice Institutionalism. Four variables that can encourage policymakers to take up or disregard a particular solution are considered: (1) the impact of vertical hierarchy the nature of the interactions between different management levels; (2) the influence of policy 


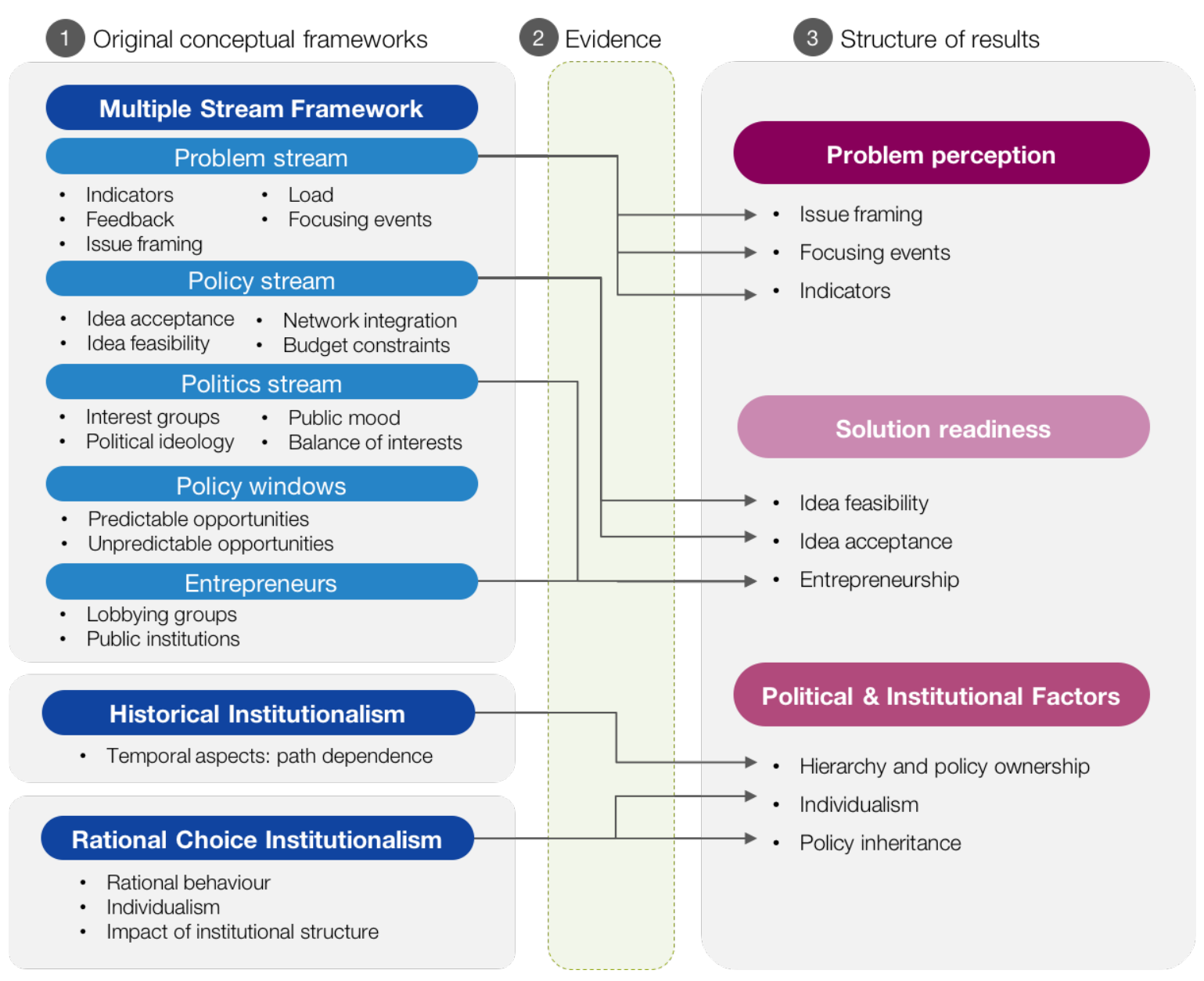

Figure 4: Conceptual framework used to structure the analysis of interviews and policy documents

ownership, that is, which venues own what policies; (3) the effect of policy inheritance, or in other words the influence of past policy developments; and (4) the role of individualism, i.e. rational behaviour. These elements also include the high- and low-level modes, described in Section 2.3, which explain the dynamics of the Commission's institutional structure.

Last, we explore the readiness of ME as a policy solution. Three specific aspects are covered, based on interview discussions: the technical feasibility to implement this; whether it aligns with the prevailing normative values of policymakers - its value acceptance; and the role played by policy entrepreneurs, i.e. the actors pushing for specific policy solutions. These aspects are described in Kingdon's policy and entrepreneurship streams (Kingdon, 1984), and also widely discussed in the literature (Bache, 2013; Zahariadis, 2008; Herweg, 2016).

\subsection{Reviewing policy documents}

The review of policy documents helps quantify the prominence of different public problems and policy solutions over time in each Directorate. Two separate analyses were conducted.

First, individual policy documents were examined in search for relevant themes. These were chosen according to the variables in Figure 4 above. We researched over ten types 
Table 2: Influential factors according to the associated theory and comments on the relevance to this work

\begin{tabular}{|c|c|c|c|}
\hline Influencing factor & Associated theory & Relevance & Explanation \\
\hline Indicators & MSF (problems) & Yes & $\begin{array}{l}\text { Explicitly mentioned in interviews across all } \\
\text { policy areas }\end{array}$ \\
\hline Load & MSF (problems) & No & Not mentioned in interviews \\
\hline Focusing events & MSF (problems) & Yes & $\begin{array}{l}\text { Obtained through the review of policy doc- } \\
\text { uments (Commission meetings), and briefly } \\
\text { discussed in interviews }\end{array}$ \\
\hline Feedback & MSF (problems) & No & Not mentioned in interviews \\
\hline Interest groups & MSF (politics) & Yes & $\begin{array}{l}\text { Explicitly mentioned in interviews; discus- } \\
\text { sion is limited - data collection is challenging } \\
\text { due to sheer volume of entrepreneurs }\end{array}$ \\
\hline Balance of interests & MSF (politics) & No & Not mentioned in interviews \\
\hline Political ideology & MSF (politics) & No & Not mentioned in interviews \\
\hline Public mood & MSF (politics) & No & $\begin{array}{l}\text { Discarded by EU policy experts (Herweg } \\
(2016))\end{array}$ \\
\hline Budgetary constraints & MSF (policy) & No & $\begin{array}{l}\text { Discarded by EU policy experts (Zahariadis } \\
(2008))\end{array}$ \\
\hline Idea acceptance & MSF (policy) & Yes & Explicitly mentioned in interviews \\
\hline Idea feasibility & MSF (policy) & Yes & Discussed in interviews \\
\hline Network integration & MSF (policy) & Yes & $\begin{array}{l}\text { Explicitly mentioned in interviews across all } \\
\text { policy areas }\end{array}$ \\
\hline Policy windows & MSF (windows) & No & $\begin{array}{l}\text { Limited understanding - Challenging to } \\
\text { develop meaningful analysis of windows } \\
\text { throughout the entire period considered }\end{array}$ \\
\hline Entrepreneurship & $\begin{array}{l}\text { MSF } \\
\text { trepreneurs) }\end{array}$ & Yes & $\begin{array}{l}\text { The Commission is treated as the main pol- } \\
\text { icy entrepreneur (Herweg (2016); Zahariadis } \\
\text { (2008); Nowak (2010); Maltby (2013)) }\end{array}$ \\
\hline Path dependence & HI & Yes & $\begin{array}{l}\text { Explicitly mentioned in interviews regarding } \\
\text { DG Environment }\end{array}$ \\
\hline Individualism & $\mathrm{RCI}$ & Yes & $\begin{array}{l}\text { Explicitly mentioned in interviews regarding } \\
\text { DG Environment and the Commission }\end{array}$ \\
\hline Institution structure & $\mathrm{RCI}$ & Yes & $\begin{array}{l}\text { Explicitly mentioned in interviews regarding } \\
\text { DG Environment and the Commission }\end{array}$ \\
\hline
\end{tabular}

of documents - more than 30 documents - as summarised in Table A.5 of the Appendix. Particular focus was placed on the developments of the three most relevant Directorate Generals (DGs) within the Commission, as identified in Section 2.1: (1) DG Energy; (2) DG Environment; and (3) DG Clima.

Second, a systematic coding approach was taken to quantitatively assess the historical importance of energy, climate and environmental topics on the EC's political agenda. This was inspired by work from Baumgartner et al. (2002) and later Princen (2009). To do this, the number of times a word is mentioned in the minutes of the weekly Commissioner meetings (over 230 documents) was quantified - from the $11^{\text {th }}$ of January 2012 (EC, 2012) to the $12^{\text {th }}$ July of 2017 (EC, 2017a). The words searched included: "energy efficiency", "resource efficiency", "circular economy", "GhG emissions" and " $\mathrm{CO}_{2}$ emissions". This serves as an indicator to evaluate the scope of the EU's environmental, climate and energy agendas, as well as the framing of ME across the Commission. The database with all the Commissioner meeting minutes can be found in EC (2017b). 


\subsection{Conducting semi-structured interviews}

Semi-structured interviews were conducted with fifteen participants from a range of institutions that are involved in shaping policies that influence industrial resources (materials and energy) and emissions. These took place between April and October 2017, and lasted between 40 and 60 minutes. Participants covered a wide range of profiles, including junior and senior civil servants, industry practitioners, consultants, researchers and sustainability officers. Table 3 lists the organisations covered in the interviews.

Table 3: Organisations covered in the semi-structured interviews

\begin{tabular}{ll}
\hline Organisation name & Type \\
\hline worldsteel & Industrial steel association \\
Tata steel & Steel company \\
Arcelor Mittal & Steel company \\
International Energy Agency & International expert institution \\
DG Energy & European Commission Directorate General \\
DG Clima & European Commission Directorate General \\
DG Environment & European Commission Directorate General \\
DG Growth & European Commission Directorate General \\
Joint Research Center & European research center \\
Public policy consultancy & International expert institution \\
\hline
\end{tabular}

Interview protocols were prepared prior to the interviews. Table 4 portrays an example. Although most interviews followed this general structure, these were at times adapted to reflect interviewee's priorities and ensure a natural conversation. Guidance on the preparation of interview structures and questions was obtained from Cloke et al. (2004), Longhurst (2010) and Cooper-Searle et al. (2017). The questions were designed to provide insights into the multiple variables identified from the literature (summarised in Section 4). The open-ended and semi-structured nature of the interviews made it possible to collect and analyse data simultaneously, and to thereby refine the line of questioning.

Interviews were transcribed verbatim using the F5 software (F5 Networks (2017)). Transcripts were manually classified into themes according to the variables in Section 3.1. For example, if participants mention the Commission's 'structure' or 'hierarchy', these statements are categorised under 'institutional analysis'. Interviewees were asked to review their interview quotes to ensure their correct interpretation. The combination of policy documents and interviews made it possible to construct a methodical and thorough explanation of why ME has received little attention as a tool in energy and climate agendas.

Increasing the sample size proved difficult given the time available to perform this work, and the overloaded schedules of relevant stakeholders - six people were unable to participate.

\section{Problem perception: framing, tracking and receiving feedback}

Before taking action, policymakers must first be convinced that a problem exists. In agendasetting, many factors affect the perception of a problem, in this case of ME. Our empirical 
Table 4: Example of prepared questions for semi-structured interviews

\begin{tabular}{lc}
\hline Personal background \\
\hline 1 & What is your job? What does it consist of? \\
2 & Are you involved in making/advising decisions on resource or energy efficiency? \\
3 & Have you been involved in a project concerned with EE/RE in energy-intensive industries? \\
\hline Questions relevant to the specific organisation \\
\hline 4 & How is your organisation involved in making or advising policies on EE/RE/emissions? \\
5 & How were you involved in the EED review consultation? \\
6 & Does your organisation incentivise the implementation of EE/RE/ME measures? \\
\hline Understanding of link between energy and resource/material efficiency \\
\hline 7 & What potential does your organisation see for RE/ME to help reduce energy use? \\
8 & How do you view energy efficiency in relation to other policy areas such as CE and RE? \\
\hline Perception of problem \\
\hline $9 \quad$ Do you think there is a need to include material efficiency as a tool in energy/climate policies? \\
$10 \quad$ Hypothetically, how could your organisation support the integration of ME as a technical option \\
\hline to meet climate and energy targets? \\
\hline $11 \quad$ Thinking about industrial climate and energy policies as a whole, what do you think are the main \\
\hline
\end{tabular}

evidence suggests that the main factors are: the rationale used to frame it (Section 4.1); the occurrence of specific predictable events (Section 4.2); and the indicators used to track it (Section 4.3).

\subsection{Issue framing: the case of material efficiency}

Figure 5 shows how frequently different topics were discussed in the Commissioner weekly meetings between 2012 and 2017. Since the launch of the RE roadmap (2011), the Commission's interest on RE/CE has steadily increased. Yet, a closer examination reveals that when $\mathrm{CE}$ is discussed, there is no mention of its energy or emissions impacts. In fact, in agreement with several policy documents (Eurostat (2017); EEA (2010); EC (2011b)), RE/CE are only discussed in relation to: resource scarcity, economic growth, price increases or security of supply. Similarly, in meetings when EE and GhG emissions reduction opportunities are discussed, there is no mention of RE/CE (see Figure 5). This indicates that RE/CE policies and energy and climate strategies are perceived as disparate policy agendas.

This disconnect is important because resource-related policies from DG Environment are driven by different rationales to the energy/climate policies from DG Energy and Clima. Under the environmental remit, $\mathrm{RE} / \mathrm{CE}$ is driven by rationales of scarcity, criticality, price increases and volatility. Resource-related fail to prioritise the energy-saving potential of $\mathrm{ME}$, for two main reasons. First, the rationale for policy intervention guides which materials should be prioritised. For example, if driven by criticality (Valero et al. (2015)), ME policies will focus on materials such as cobalt or neodynium, and neglect abundant energy-intensive materials such as iron or cement. Second, the choice of institutional venue dictates the stringency of policy enforcement in the EU, i.e. energy/climate targets are binding, whereas 


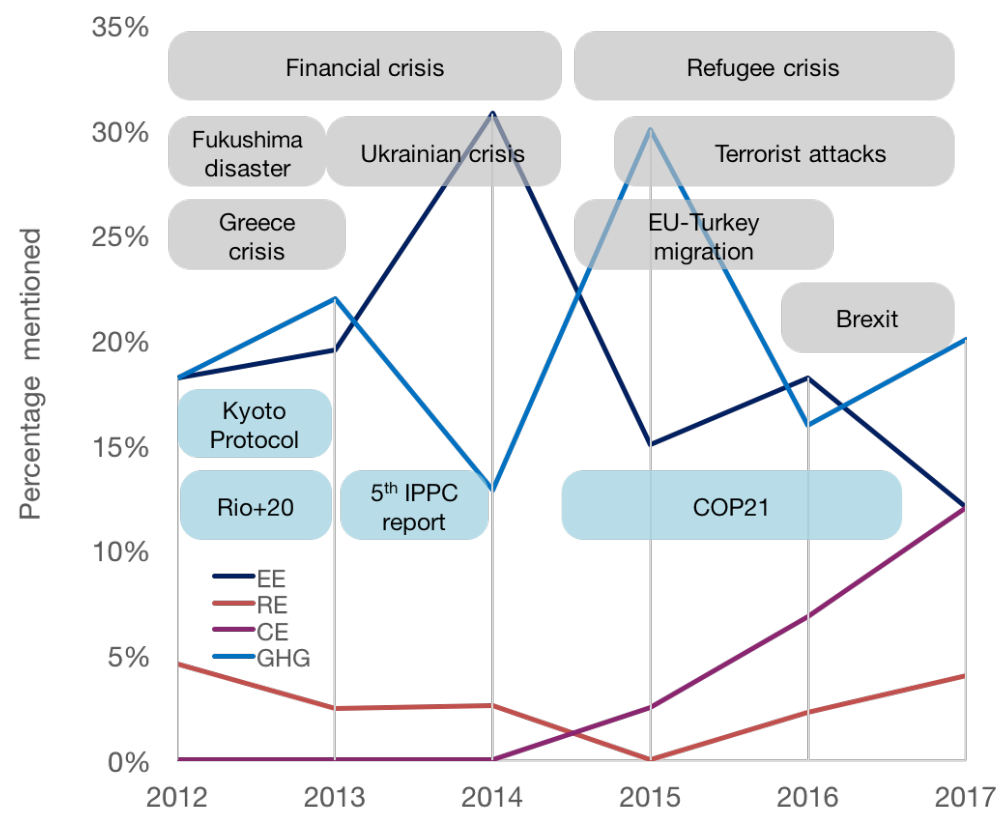

Figure 5: Topic analysis of weekly Commissioner meetings, covering energy efficiency (EE), resource efficiency (RE), circular economy (CE) or emissions (GHG), as reflected in the minutes; expressed in percentages. Blue and grey boxes indicate possible climate-related and unrelated triggering events respectively.

most ME policies, except for waste legislation, are non-binding.

Although it is not apparent from policy documents, interviewees suggested that DG Environment has attempted to reframe ME as an energy and climate, beyond an environmental tool. A report commissioned by DG Environment on the energy-saving potential of RE (Mehlhart et al. (2016)) reportedly resulted from the fact that "environmental aspects have not really been at the forefront". Another interviewee concurred, stating that this report enabled DG Environment to highlight that "there is also an energy dimension to [ME]". The report explicitly states that "while RE policies are worth pursuing in their own right for reducing environmental pressures, the induced energy savings provide a further rationale for their urgency".

There is a precedent for reframing and expanding policy agendas in the EU. Originally, EE was primarily motivated by energy security and economic growth. However, in 2007, the Commission launched its first combined energy and climate policy framework (EC, 2008b). Since then, the convergence between these two issues has continued. For example: there is now a single Commissioner for Energy and Climate Change; and the Energy Union is due to combine the governance of energy and climate data collection mechanisms. The reframing of EE, however, had widespread support from academics and industry experts, including the IEA (2010, 2013), which is currently more limited for ME. 


\subsection{Focusing events: influence of scheduled feedback opportunities}

Specific events can turn policymakers' attention to certain public problems or solutions. These can be predictable e.g. the scheduled renewal of legislation, or unpredictable e.g. periods of crises. Evidence from the interviews revealed two points. First, that although unpredictable events (see Figure 5), might have been potential windows of opportunity for a more integrated $\mathrm{RE} / \mathrm{EE} /$ climate policy agenda, this did not happen. Second, that policy entrepreneurs exploited the opportunity provided by predictable events, such as public consultations, to voice the need to integrate resource-related policies with energy and climate strategies.

A high-level Commission official explained that "things can come on to the agenda through consultations" and that the EC "use[s] the responses to the consultations [...] to come up with new ideas and to understand better the balance of opinions". Yet, this was not the case in the two EED consultations conducted in 2014 (EC (2014b)) and 2016 (Directorate-General for Energy (2016)), where industry stakeholders voiced the need to incorporate ME as a tool to achieve energy and climate goals: "[EE goals] must be kept in balance with [RE] goals". This high-level official, explained that "it was not the judgment of anyone in [DG Energy] that there was anything in the consultation that we should pick up on".

Responses suggesting the need to integrate RE and EE/climate policies, however, were sparse, did not suggest specific policy changes, and were overshadowed by responses alluding to other concerns such as the stringency of EE targets for 2030 or the regulatory and market changes required to improve investments in conventional EE measures already considered by the directive. From the responses to the EED consultations it can be concluded that there is no dedicated industry stakeholder group that advocates for the implementation of ME.

Specifically referring to energy and climate policies, one interviewee mentioned that policymakers tend to resist "any suggested policy change... and if it is not suiting their agenda, they will probably allow you to write down the changes that they wanted to do anyway inside your policy measures". The participant concluded that this limits the extent to which these policies can be influenced through consultations, as these lead to "a lot of inconsequential very small changes but no overarching support or impact". This finding agrees with incrementalist policy theories, as defended by Lindblom (1959), which state that unless a catastrophe occurs, policy developments will happen "through a series of relatively small changes".

\subsection{Multiple indicators: tracking material efficiency}

A change in an indicator can sometimes bring attention to a particular policy agenda. EE and ME policy areas are saturated with indicators (see Table A.6 in the Appendix), which means policymakers need to interpret their relative importance. Evidence suggests that $\mathrm{ME}$ metrics are inadequate, mainly because these often exclude the embodied energy reductions associated with reductions in the use of energy-intensive materials. However, even when embodied energy metrics are included, they may carry little weight among policymakers. Interviewees offered three explanations. 
First, environmental indicators are mostly consumer- rather than producer-centric. One of the interviewees admitted that the $\mathrm{RE}$ and upcoming $\mathrm{CE}$ monitoring frameworks "are not targeted at producers", but rather at supporting the assessment and labelling of products to influence consumers. This suggests that embodied-energy-type indicators are more commonly used to inform end-user decisions and that there is less experience in using these indicators within climate and energy policies targeted at producers.

Second, the RE, CE and Raw Materials frameworks don't currently track the energy embodied in materials. One interviewee explained that doing so would be challenging because the "market surveillance authorities [...] don't do life-cycle", meaning that they do not consider the energy consumed across the product's full life. Omitting the upstream energy embodied in materials weakens the incentives to promote ME as a solution to reduce energy. This lack of embodied-energy indicators also besets EE policies and the ETS (EC (2009a, 2013)), in which only direct energy use and emissions are included.

Yet, even if life-cycle type indicators capturing the embodied energy associated with material use were to be tracked, three interviewees signalled the lack of clarity around LCA and resource productivity indicators makes them difficult to operationalise and interpret. One interviewee highlighted that the "measurement of $R E$ was considered very imperfect and there was a lot of controversy", but asserted that this "was always acknowledged". This view was supported by another interviewee, who explained that "one of the problems with the leading indicator [was that] it didn't mean anything to many industries". Regarding LCA metrics, one interviewee explained that "embodied energy is a value judgement". Another said that:

"the more you start to compare at the small scale, the more you are confronted the need to do allocation [...] if you want to have a subset of a system and compare, then that's tricky".

Cooper-Searle et al. (2017) posit that this results partly from the "lack of standardisation" and partly "from the uncertainty and complexity associated" with these.

Lastly, data available on material flows is limited. As pointed out by one interviewee, the controversy over the current lead indicator is exacerbated because "there is a lot more data that is needed, for example the magnitude of waste streams and their energy contents".

\section{$5 \quad$ Political and institutional factors}

Our evidence suggests that four institutional and political factors affect the agenda-setting process in the EC: its vertical hierarchy and policy ownership (Section 5.1); the behaviour of individual actors (Section 5.2); and imposed policy inheritance (Section 5.3).

\subsection{Vertical hierarchy and horizontal policy ownership}

The term vertical hierarchy refers to the interactions between management levels within the Commission, whereas that of policy ownership refers to the parallel interactions across 
directorates. Section 2.3 mentions the relevance of the mode of issue expansion, for which Princen and Rhinard (2006) proposed two alternatives: through high- or low-level politics. Interviews confirm the importance of high-level support in integrating ME across other areas, and emphasise the Commission's hierarchical rigidity.

One interviewee explained that a policy agenda will depend on whether "there is a very important top-down element; who is the Commissioner, who is the President; what priorities they set" and said that "all of this is a bit beyond our control". Another suggested that since 2011, there has been a lack of buy-in from political leaders. He argued that "the Commissioner needs to be on board for this level of change to occur" and that without high-level support they "couldn't really ever convince any of the other DGs to take [RE] seriously as an initiative, because there wasn't buy-in from the director general". This also meant that "the rest of the $D G$ [did] not really get RE or how it might work".

These statements highlight the relevance of high-level politics within the Commission and reveal that enacting policy changes is further complicated by the Commission's "pretty rigid hierarchy". To date, there is little evidence that ME is a priority issue for senior EC representatives in DG Energy and Clima, and that this could help to explain the lack of prominence it has relative to climate and energy strategies.

Interviews revealed that the cross-directorate policy ownership of environmental, energy and climate matters can hinder the integration of $\mathrm{ME}$ in energy and climate policies. One interviewee explained: "the Commission [has] silos which have their own agendas and instruments and even in the same DG there are different units with different objectives and [...] instruments".

Another reckoned that better cross-DG coordination is needed: "the director generals need to talk to other director generals and sell them the benefits of mutual cooperation, then these would tell the directors who would tell the head of units, who would tell the staff to work together. But without that everyone is busy doing their own thing".

Discussing the RE initiative (EC (2011b)), another recalled the poor relationship between different Directorates: "there was a huge amount of frustration between the Cabinet and DG environment with the Director general in the middle". Discussing DG Energy's involvement in DG Environment's report on the "Energy Saving Potential of Increasing Resource Efficiency" (Mehlhart et al. (2016)), one interviewee from DG Environment mentioned that although they were involved internally, they were "not tremendously engaged". In discussing the interactions between these three DGs, one interviewee explained:

"Everyone wants to control their own policy [...] It's a big hassle if anyone else tries to change it. Firstly, because they don't control it... Secondly, because it makes it more complicated. Thirdly, because they don't have the time. Fourthly, because changing policies sometimes opens up policies to debate [...] which can lead to unforeseen, unwanted changes in the policy which people are already working on". 
Yet, the segregation of energy, climate and environmental matters across multiple Directorates is not unique to the EC. Its pervasiveness also affects national governments and industry firms. One interviewee explained that, in national governments: “...an energy, economic or industry department might deal with [...] energy, and then issues [on] resource efficiency and waste will probably be with an environmental department".

\subsection{Individualism in decision-making}

Interviews reflect that the motivations for paying attention to given policy solutions can be affected by the specific people involved in the decision-making process. Five interviewees mentioned the importance of the personality and skills of specific individuals in the development of both environmental and climate policies.

In reference to the environmental agenda, one interviewee explained that RE "was Potočnik's thing at the time, and now we have a new Commission and a new Commissioner and the new big thing is the CE". While discussing the overlap between EE and the ETS, another argued that "[Dimas] had his big idea, and didn't want to jeopardise it" by incorporating EE improvements. A third interviewee mentioned that in understanding why a specific issue does not receive attention it is important to consider the "dynamics of the posts and people... who is in what post and how these people connect with other people in other DGs".

The skills and previous experience of specific actors were revealed to play a relevant role in determining the success of an issue in reaching the political agenda. One interviewee highlighted that "[Commissioner Potočnik] came from innovation so he knew a lot about innovation and about economics [...] and was interested in win-wins between economics and the environment". He also explained that the fundamentals behind the RE strategy were "very much Potočnik's perspective on how things could move forward".

Section 5.1 revealed that a cross-Directorate issue such as ME, is more likely to become an energy/emissions instrument if this is promoted from above (i.e. through the high politics route). The relevance of people's individual interests highlighted in the interviews suggests that for ME to be appropriately integrated in energy and climate policies, a high-level policymaker is likely to need to be personally committed to engineering this. As the EC's priorities have been long set (in 2014) and its current term is coming to an end (in 2019), it seems improbable that any change will occur before a new Commission is elected.

\subsection{Policy inheritance}

Incorporating ME measures to energy and climate agendas will require overcoming the resistance imposed by previous policy developments. In this study, interviews confirm that the hostility faced can be largely attributed to the policy lock-in created by the ETS - the crux of the EUs climate policy.

Four interviewees agreed that the most feasible option to incorporate ME is to improve the 
ETS in order to make this the main energy/climate policy for heavy industry. Yet, there is disagreement about how to do this. One stated that "we should improve [the ETS] by turning it into a global emissions trading system, with a very limited cap that evolves in line with the Paris agreement". Other suggestions included appropriately capturing the effect of EE, and adjusting the carbon price. One interviewee suggested that "getting the price right is the right thing to do". Another reckoned that "there is the psychological effect [...] in industry of extended periods of high prices".

Other participants were more critical about the effectiveness of changing the ETS. One contended that "there is evidence that changing the prices might not alter the uptake of $E E$ " and that they are unlikely to trigger structural changes in firms. Academic experts support this view and relate the ineffectiveness of carbon prices to four factors: the adoption of carbon-leakage prevention mechanisms ${ }^{5}$; the fact that cost effects downstream depend on mitigation decisions made upstream; imperfect competition and cost pass-through (Skelton and Allwood (2017)).

Modifying the ETS will also require overcoming resistance from industry stakeholders, who are anxious to avoid conflicts with other policy areas and concerned about the scheme's effect on competitiveness. In an impact assessment, the EC (2015a) reported that: "many stakeholders claim it is difficult especially since the products are traded on global markets, while others underline that determining concrete cost-pass through rates may be challenging as many factors are at play".

The historical developments of the ETS are key to understanding the options available for bringing ME into the energy and climate agendas. Indeed, the 'increasing returns' dynamic behind the ETS is likely to be detrimental to both the technical feasibility and the idea acceptance of integrating ME in energy/climate agendas.

\section{Solution readiness}

Interviews show that a solution is more likely to receive attention if it: is technically feasible, aligns with the Commission's values, and there is consensus among the policy community. These three aspects are discussed in Sections 6.1-6.3.

\subsection{Technical feasibility}

For a specific idea to not only stand out, but to "survive to the point of serious consideration" (Kingdon, 1984), that idea must be technically feasible. One interviewee explained that the EU has "a very rich set of legislative instruments of different types and [...] also more potential...there are all sorts of things we could do." The wide-ranging implications and drivers for reducing material use, however, make it challenging to develop policies that fully

\footnotetext{
${ }^{5}$ For example, in the UK, at least $95 \%$ of ETS allowances are allocated for free to the steel sector (Allwood and Skelton (2017)).
} 
capture all of its nuances. And as revealed in the interviews, this makes it hard to find appropriate solutions to leverage the energy- and emissions-saving potential of ME.

One interviewee reckoned that incentivising ME requires "systemic change...going beyond individual policies to creating the right framework", i.e. reflecting interdependencies between industrial energy use and emissions across an entire value chain or sector. Another suggested that "until we know more it is difficult to know what the right instrument would be". With relation to DG Environment's report on the energy-saving potential of ME (Mehlhart et al. (2016)), a third interviewee mentioned that they "found it very difficult to come to concrete policy suggestions" and that "in terms of policy conclusions that could be taken up at the EU-level, [the report] didn't really serve that purpose".

This could be associated with the fact that, as suggested by two interviewees, ME is prohibitively technical, which could make it challenging for policymakers to operationalise. One believed that there is still "a learning curve that governments and industry need to work through and it would be quite steep" and "[the Commission] need[s] even more concrete examples of the energy saving potential of RE". Another explained that "the thing with RE is that the concepts are understandable mainly to a technical audience [...] but translating that into policy is obviously more difficult".

Despite this complexity, several interviewees offered ideas of how to integrate ME into current and forthcoming EU policies. One suggested that "the area where you are going to see most discussion about the relationship between RE and EE is in Eco-design in the next couple of years". Developing minimum standards for the ME of new EU appliances/devices, e.g. for durability or recyclability, can be appealing because Eco-design has low levels of subsidiarity. This same interviewee further explained that if " $a M S$ wants to see efficiency grow [this can] rely on better products coming into the market without doing anything other than voting for it in the [EU's] decision-making process". Another proposed modifying environmental policies: "there are other policies that are important, water and waste legislation...anything that improves processes, so the IED has some impact on resource use". The IED develops the BREFs - best practice reference documents - which provide guidance on EE options for sites to reduce emissions. Albeit not covering $\mathrm{CO}_{2}$ emissions, BREFs could provide technical support if the given ME measures proposed also reduce other emissions.

For these ideas to materialise into policies, they would need to get buy-in from multiple directorates and policy areas. Yet, in practice this may prove challenging. One interviewee reflected on the current lack of integration between energy and climate policies, "it is really frustrating that they didn't want to factor in EE into the ETS [...] this has been extremely harmful to energy and climate policies over the past 10 years". This could result from organisational and political factors. As one interviewee speculated "[DG Clima] didn't want to have anything to do with EE. [Policymakers in charge of] the ETS never really wanted industrial EE regulation to happen". Challenges faced in integrating energy and climate policies could act as frictional barriers towards incorporating a third policy area. 
Interviewees also mentioned operational factors that may affect technical feasibility. One mentioned the fact that policymakers "are dealing in some cases with data issues", specially in policies on secondary material use, where "sharing data across the system is necessary to ensure the quality of recycled material". Another reckoned that there is a lack of methods to ensure that MSs "are accounting properly for what happens in their territory or in other people's territory".

The technical feasibility of integrating ME into energy/climate strategies is not fully understood. However, interviewees perceive that integrating ME incentives into climate and energy policy will be taxing because of institutional, political and operational factors.

\subsection{Idea acceptance}

For policymakers to accept an idea, everyone in the policy community would need to have a similar understanding of what the idea is. This, however, is not the case for ME.

Although participants were all familiar with the term 'material efficiency', its exact interpretation varied. Most participants were only familiar with a selection of ME measures, but did not acknowledge that they encompass an umbrella of strategies (see Allwood et al. (2011)). Two recognised material by-product use as a ME strategy. One gave the example of "the use of slags of course [...] the slag you can valorise for cement use". Another mentioned industrial symbiosis, "...[in] a steel plant that produces some gases in the blast furnace, we have CO and so this can be a feedstock in the chemical industry". Two other interviewees gave recycling as the main example. Others were even disparaging about its value; one interviewee voiced concern over the lack of a widely-accepted definition: "[RE] is just a buzzword, it means many different things to many people".

Beyond the lack of common understanding, the interviews revealed other two factors that might impact on idea acceptance: confusion over the link between energy and material use, and the potential trade offs and conflicts with other policy goals.

When asked about the link between material and energy use, three interviewees interpreted this as the resource use associated with EE actions, as opposed to the energy savings from reducing material use. For example, one mentioned the "need to know more about the resource impact of our policies". Another argued that "if you improve processes to save emissions you might have some resource savings at the margins, but I don't think the resource impact is currently quantified". Only one interviewee mentioned that "it's important to acknowledge that there is obviously embedded energy and embedded energy cost that are in materials that is potentially wasted as part of industrial processes".

Some interviewees believed that leveraging ME's energy-saving potential may be challenged by the need to simultaneously support other drivers. One explained that if ME is merely driven by its energy- or emissions-saving implications this would "help on some resources but not on others". Another said that "there are situations where they might work against each 
other. Some measures can conflict or contradict". Another believed that "EE doesn't help in the circularity argument" and that "EE policies are not in sync with the transition to a circular economy". Three participants mentioned contradictions in the buildings sector. One explained that "EE policies are only linked to use-phase consumption" and that they "are not looking at the whole system, so they are coming up with bad measures". Although there was no mention of heavy industries, perceived conflicts in other sectors, such as buildings, can influence policymakers' disposition to intervene.

\subsection{Entrepreneurship}

Kingdon (1984) posits that policy solutions gain prominence through multiple channels, including concerted activities by policy entrepreneurs inside and outside the responsible public institutions. In this context, policy entrepreneurs are advocates who promote specific policy solutions in the hope for future gains "in the form of material, purposive or solidary benefits" (Kingdon, 1984). In this study, entrepreneurship is understood to be important in raising the profile of ME solutions in the EC, as suggested by the empirical data collected.

Interviews unveil the relevance of expert institutions. For example, one interviewee mentioned specific researchers that promote certain ME measures: "in the working group the European Energy Research Alliance also have their word in defining priorities". Another revealed that the European association of SPIRE (2017) is particularly influential. Yet, despite the existence of some support, some interviewees suggested the need for more. One stated: "I think the fact that the IEA hasn't covered [ME] that much means that in some cases policymakers haven't seen it either". The IEA's limited promotion of ME to date may have a definite effect on EU policymakers, as the agency's reports are considered trustworthy sources of expertise.

This agrees with Klüver (2013), who contends that for highly technical issues, the EC has to rely heavily on lobbying groups as these possess expert information. The author believes that in these cases the general population is likely to be less engaged. In fact, Smith (2017) concludes that media coverage on ME consists of "sparse rehearsals" that critique consumption, and that "the relationship between environmental change, material consumption and everyday life" must be re-framed and made more positive and tangible.

Less prominent is the support provided by industry stakeholders. One interviewee claimed that the EC "would not want to undermine the position of industry", and that for an idea to become part of the industrial policy agenda, this would at least require buy-in from industry itself: "ideas have to come from industrial stakeholders". Yet, while EC officials mentioned the relevance of industry in the development of industrial policies in general, they did not mention the existence of a group that promotes ME as an energy/climate solution.

Despite the existence of some ME advocates (e.g. the European Climate Foundation (Circle Economy, 2017)) interviewees did not reference a lobby group that specifically promotes ME as an energy/climate solution. This suggests that either there are insufficient proponents of ME for industry or that their initiatives have had little success in reaching influential decision- 
makers. The latter may be due to the fact that support for ME is relatively recent. However, measuring the role played by entrepreneurs and the impact these have on policymakers decisions is an extremely taxing endeavour; it is difficult to capture the effort going in to promote an idea and the involvement of specific entrepreneurs is rarely mentioned.

\section{Policy implications: potential interventions}

The above sections evaluate the factors preventing ME from becoming part of the EU's energy and climate agendas. Although ex-ante analyses make it impossible to know how events will unravel, the knowledge gathered places us in a good position to make future suggestions. Table 5 (spread over three pages) summarises the avenues that could be explored to incentivise the adoption of ME as an industrial energy/climate tool. This table compiles a list of interventions that are based on suggestions made by interviewees and on solutions recommended in the literature. Interventions are classified according to the degree (whether a minor, intermediate o major change) and type of change that is required (whether informational, technical, financial, legislative, executive, or administrative).

If the ETS remains the province of industrial climate policies and the evidence presented above proves accurate, sudden events and institutional turnovers are most likely to trigger the policy changes required to integrate ME in climate/energy agendas. Potential outside events that could initiate a policy shift include: (1) the unexpected shortage of a given resource; (2) unforeseen trade tariffs on energy-intensive materials, e.g. Americas new tariffs on steel; (3) the need for new climate deals as a result of Brexit.

In the upcoming decade, one predictable window during which discussion on the integration of ME might be initiated, is the next revision of the ETS. But even if policymakers, industry stakeholders and Member States were to agree to make pertinent modifications to the ETS, this window is subject to the slow pace of change in EU-level policymaking: ETS revisions made at this time are not expected to come into effect until after 2030. The entrance of the new Commission in 2019 presents another opportunity for such discussion; though, again, even if the new Commission makes the integration of ME a firm objective, required policy interventions are unlikely to be enacted within their five-year term. ${ }^{6}$

A third potential catalyst for change is in the revisions of complementary measures, for example, Articles 7 or 8 in the EED. If ETS modifications prove challenging and lengthy, increasing the stringency and scope of EU-level energy and/or environmental policies becomes an effective alternative. The main drawback to this alternative is, again, that these policies are likely to be enacted after 2030 .

There are multiple reasons why EU-level action is preferred for incentivising ME: the international nature of supply-chains; the ability of EU-backed initiatives to pool public resources and attract the required quantity of private investment; the fact the EU is responsible for the

\footnotetext{
${ }^{6}$ It is possible that Brexit negotiations trigger an unforeseen revision of the ETS in 2019. It is, however, uncertain whether these negotiations will open up the opportunity to revise other provisions.
} 
governance of a large number of environmental and energy issues. However, given the barriers just discussed, it appears that major, short-term policy interventions at the EU-level are limited. The policy shift required to leverage ME as an instrument to reach energy/climate targets will therefore require action from Member States, industry and academics.

\section{Conclusions}

This article was motivated by the lack of an existing explanation on why material efficiency is currently not part of the EU's energy/climate agendas. By conducting interviews, reviewing policy documents, and expanding upon three policy theories - including rational choice institutionalism, historical institutionalism, and Multiple Stream Framework - we evaluate why this is the case. Combining these three theories provided a richer understanding of the factors influencing the Commission's agenda-setting process, than either framework would have given in isolation.

Our analysis suggests that the lack of integration of ME in energy and climate policies stems from a combination of contributing factors: difficulties in reframing the prevailing rationale to pursue material efficiency; the inadequacy of monitored indicators; the lack of high-level political buy-in from DG Energy and Clima; the ETS policy lock-in; uncoordinated policy management across multiple Directorates; and the lack of a designated industry lobby.

Time to integrate material efficiency in the EU's energy and climate strategies is limited and there are no easy solutions to do so. Yet, with adequate high-level political will, a plethora of policy actions can be executed to achieve this. Based on this evidence and the proposed interventions, we emphasise the need for Member States and industry stakeholders to drive the transition to a low-carbon heavy industry in the EU. Given the key role to be played by Member States and industry firms, the study's remit could logically be expanded to investigate the attitudes, expectations and ambitions of these stakeholders.

\section{Funding}

This research is funded by Emerson Electric co.

\section{A Appendix}

This section includes additional information.

\section{A.1 Additional information for the literature review}

Table A.1 and A.2 provide an extensive summary of the policies reviewed in this study. 


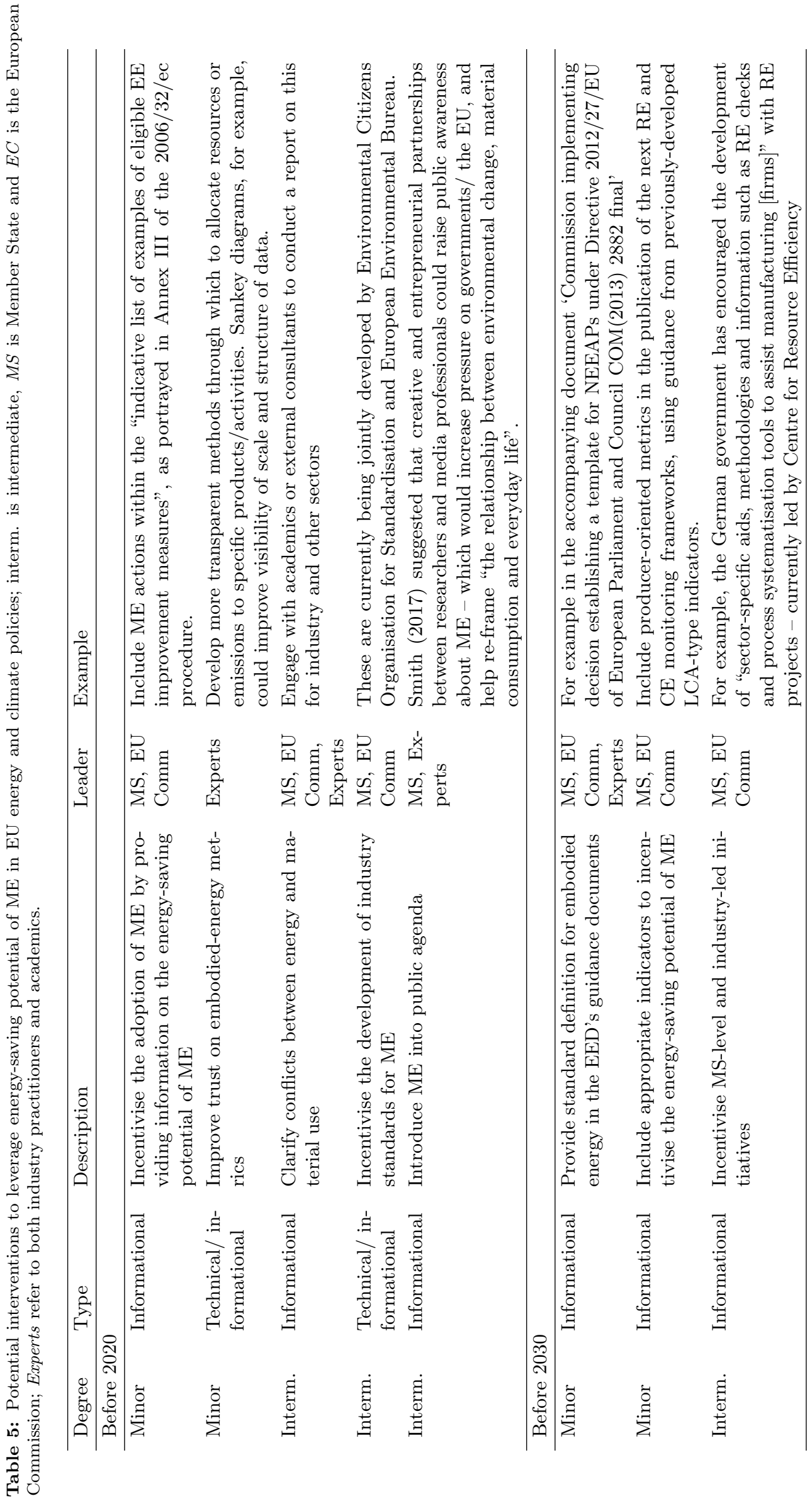




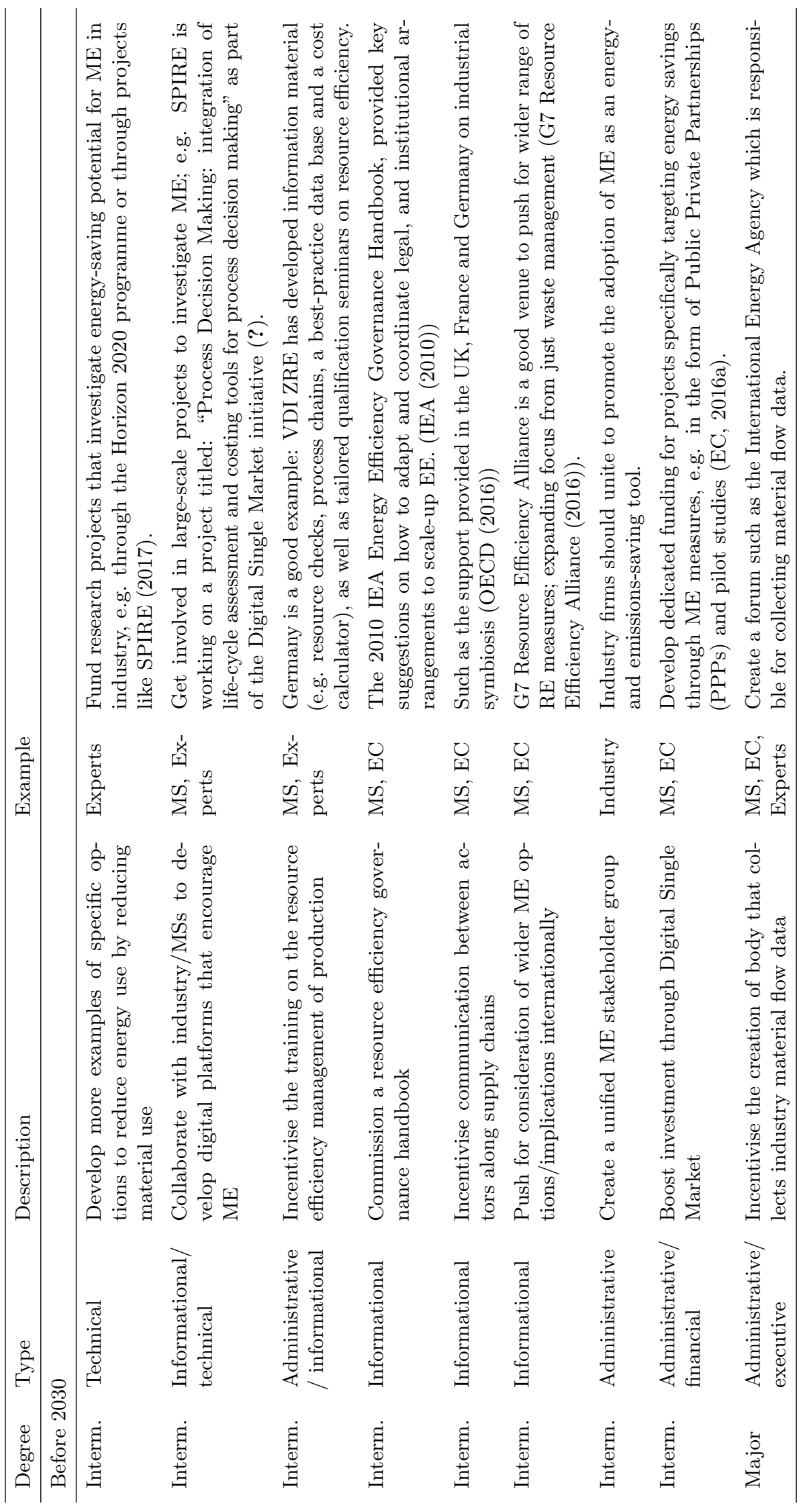




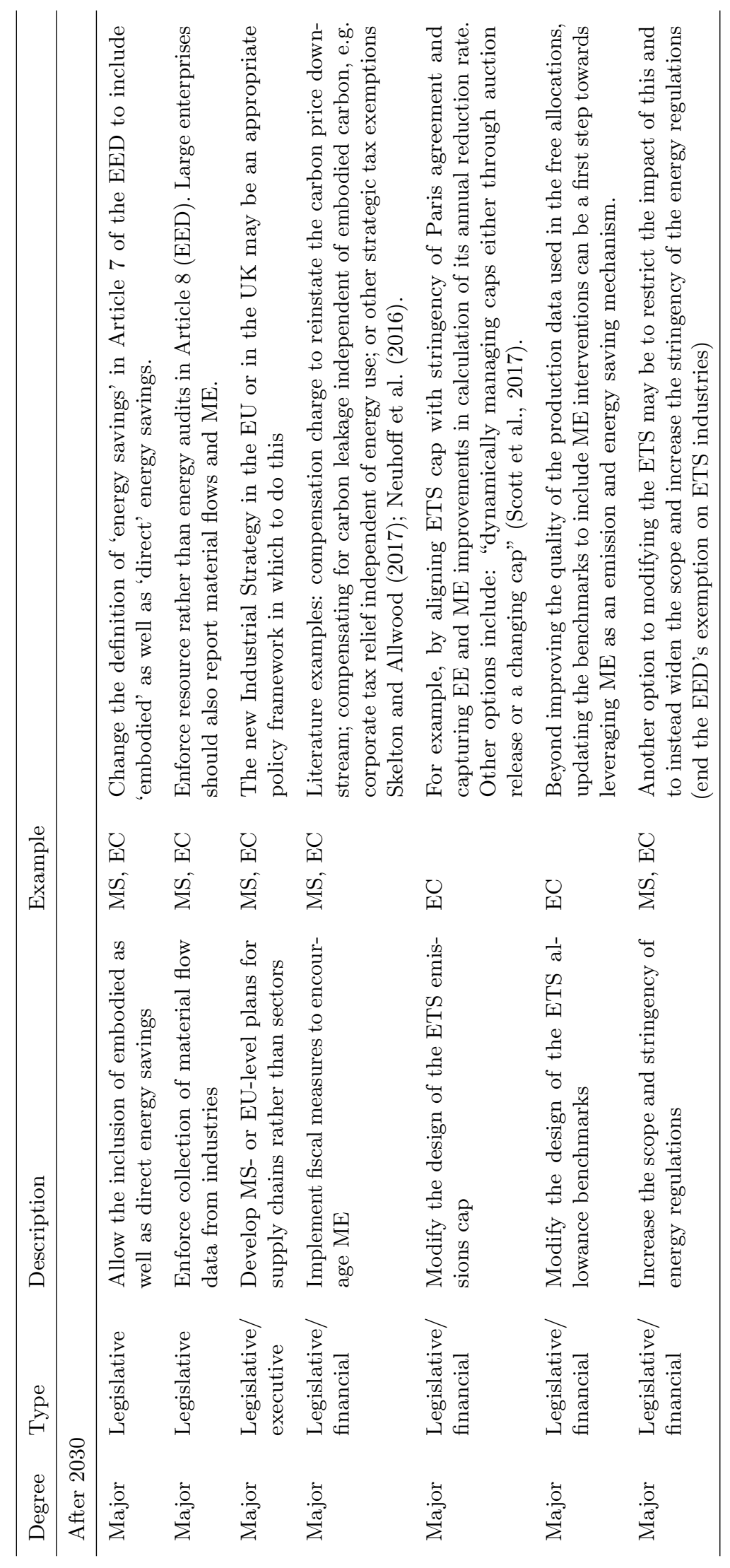




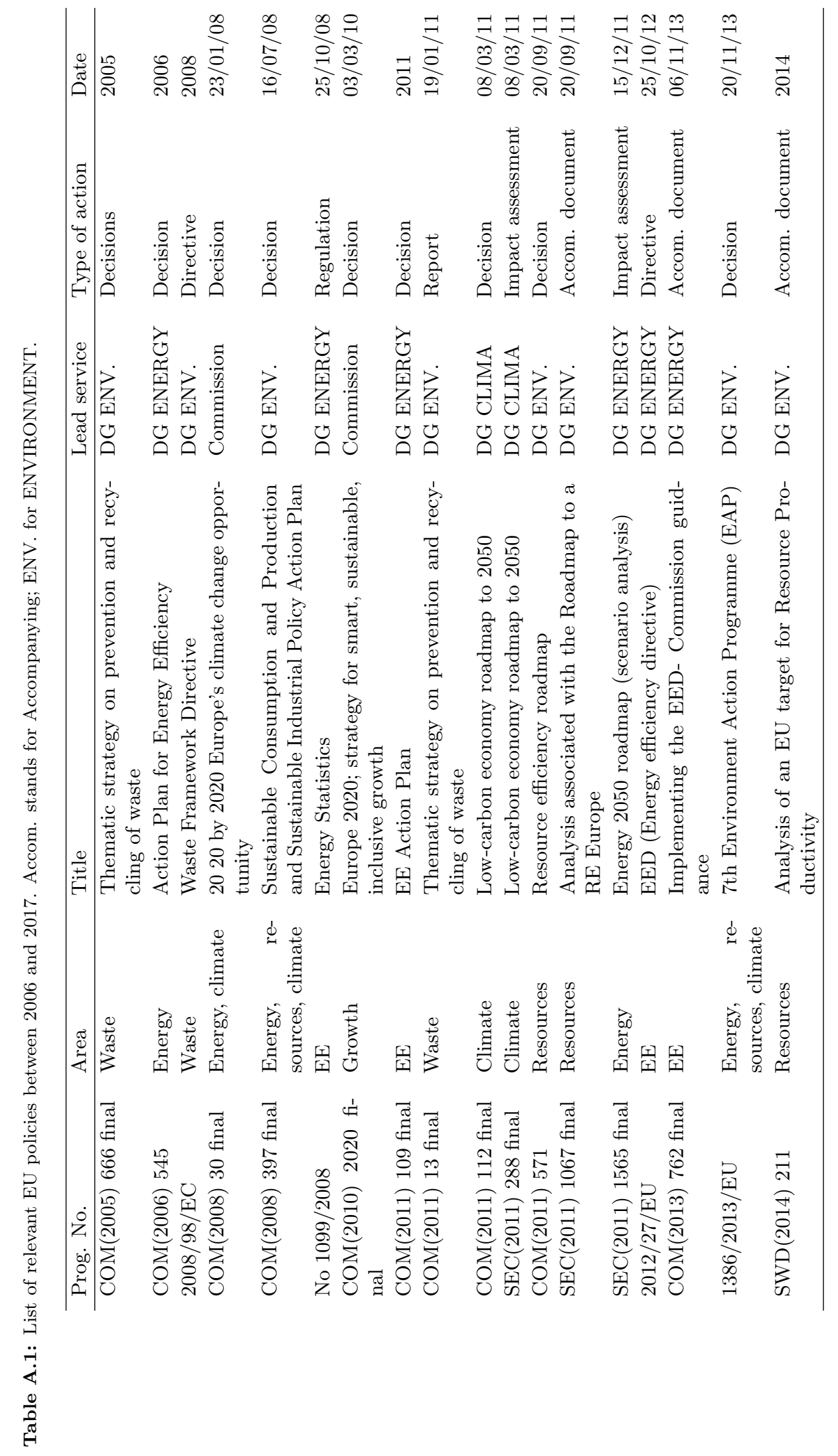




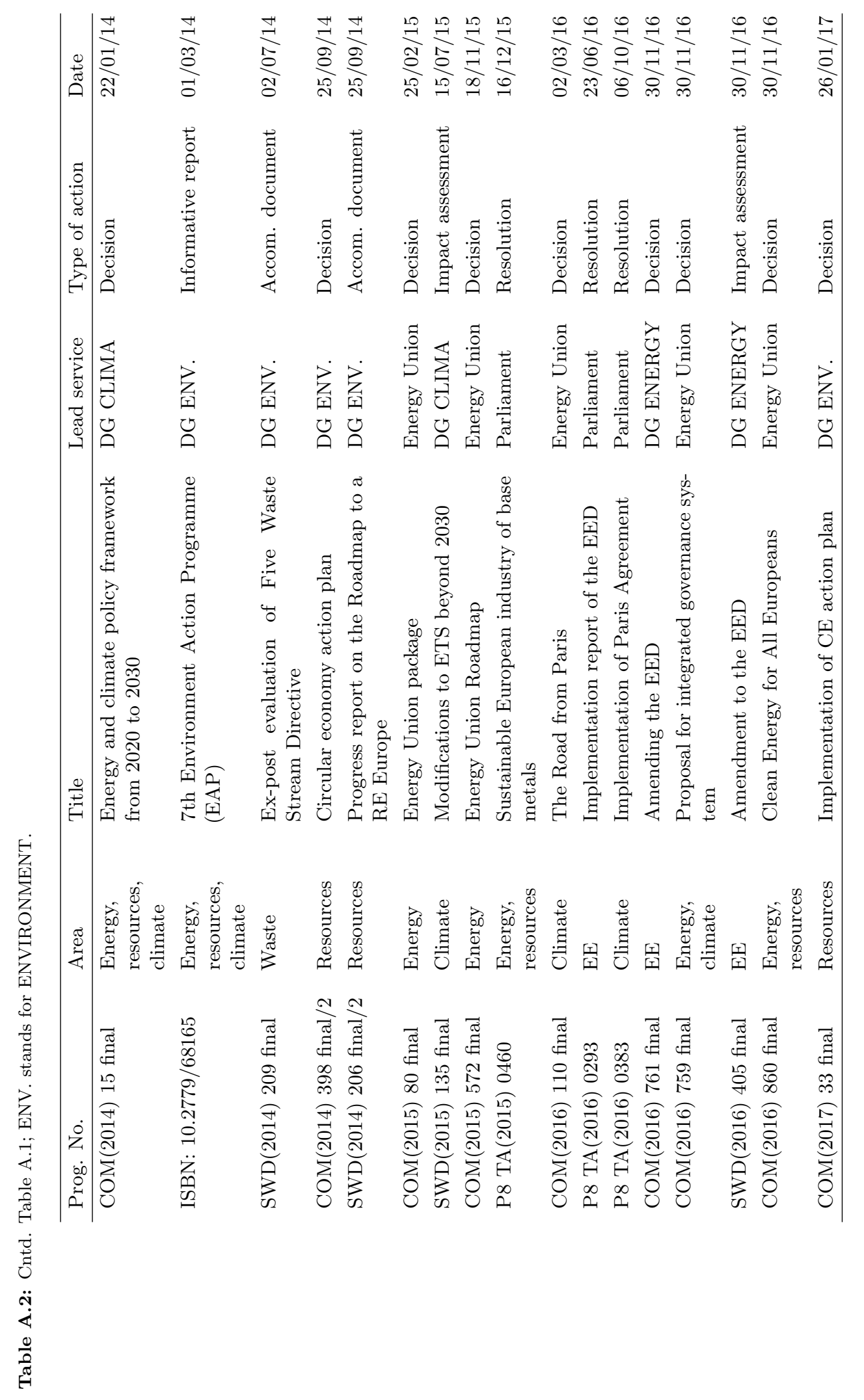


Table A.3 outlines the main features of the two issue-expansion routes described by Princen and Rhinard (2006).

Table A.3: Summary of features of the 'high politics' and 'low politics' routes for agenda-setting in the EU (Princen and Rhinard (2006))

\begin{tabular}{|c|c|c|}
\hline Features & High politics & Low politics \\
\hline $\begin{array}{l}\text { Originating actors } \\
\text { (issue expansion) }\end{array}$ & $\begin{array}{l}\text { High-ranking political figures, e.g. Com- } \\
\text { missioners }\end{array}$ & $\begin{array}{l}\text { Low-ranking Commission experts, e.g. } \\
\text { civil servants in specific units }\end{array}$ \\
\hline Problems stream & Crises, symbolic events, public mood & Changes in indicators, policy feedback \\
\hline $\begin{array}{l}\text { Risk of issue en- } \\
\text { trance }\end{array}$ & $\begin{array}{l}\text { High-level attention rapidly shifts to new } \\
\text { issues causing political impetus to fade }\end{array}$ & Can be blocked by high-level politicians \\
\hline $\begin{array}{l}\text { Opportunity of is- } \\
\text { sue entrance }\end{array}$ & $\begin{array}{l}\text { Large political impetus for change once } \\
\text { high-level politicians have committed }\end{array}$ & $\begin{array}{l}\text { Solid 'self-sustaining dynamic' by slowly } \\
\text { expanding EU activity upwards }\end{array}$ \\
\hline
\end{tabular}

Table A.4 summarises recent MSF studies applied to the context of the EU.

Table A.4: Summary of MSF studies applied to the context of the EU, modified from Herweg (2016)

\begin{tabular}{llllll}
\hline \multirow{2}{*}{ Study } & Policy stage & Policy issue & \multicolumn{2}{c}{ Adaptation } \\
& & & Streams & Window & $\begin{array}{l}\text { Entre- } \\
\text { preneurs }\end{array}$ \\
\hline Bozzini (2017) & Entire process & Pesticide regulation & - & - & - \\
Fuchs (2017) & Decision-making & Environmental governance & No & No & Yes \\
Herweg (2016) & Agenda-setting & Natural gas regulation & Yes & Yes & Yes \\
Copeland and James (2014) & Decision-making & Economic reform & No & No & Yes \\
Bache (2013) & Agenda-setting & Quality of life & Yes & No & No \\
Grugel and Iusmen (2013) & Agenda-setting & Childrens rights policy & Yes & No & No \\
Ackrill et al. (2013) & Entire process & Theory & Yes & Yes & Yes \\
Maltby (2013) & Agenda-setting & Energy policy integration & Yes & No & Yes \\
Ackrill and Kay (2011) & Decision-making & 2005 Sugar reform & No & Yes & Yes \\
Borrás and Radaelli (2011) & Decision-making & Lisbon strategy gover- & Yes & No & No \\
& & nance & & Yos \\
Kaunert and Giovanna & Decision-making & Counter-terrorist financing & Yes & No & Yes \\
2010) & & cooperation & Yes & Yes & Yes \\
Zahariadis (2008) & Entire process & General theory & No & No & No \\
Richardson (2001) & Agenda-setting & German emissions trading & Yes & Yes & Yes \\
\hline
\end{tabular}

\section{A.2 Additional information for the method}

Table A.5 summarises the types of documents reviewed in this study. 
Table A.5: Summary of policy documents reviewed

\begin{tabular}{llll}
\hline Type of document & Acronym & Institution & Time reviewed \\
\hline Commission meetings minutes & PV & Commission & $2012-2017$ \\
Draft meeting minutes Council & PV & Council & $2014-2016$ \\
European Citizen Initiatives & - & Commission & $2012-2017$ \\
Legislation proposals & COM & Commission & $2014-2017$ \\
Action plans & COM & Commission & $2011-2017$ \\
Roadmaps & COM & Commission & $2011-2017$ \\
Flagship initiatives & COM & Commission & $2011-2017$ \\
Documents relating to official instruments & C & Commission & $2011-2017$ \\
Staff Working Documents (progress reports, impact & SWD & Commission & $2014-2017$ \\
assessments etc.) & & & \\
Public consultations & - & Commission & $2000-2017$ \\
Own-initiative reports & INI & Parliament & $2014-2017$ \\
Resolutions & TA & Parliament & $2014-2017$ \\
Inter-institutional procedures & Eurlex & - & \\
National energy efficiency action plans & - & Commission & $2012-2017$ \\
Annual reports & - & IEA & $2014-2017$ \\
Annual reports & - & EEA & $2010-2017$ \\
Resource efficiency report & - & International & $2015-2017$ \\
& & Resource Panel & \\
\hline
\end{tabular}

Table A.6: List of most relevant indicators, sourced from Humphris-Bach et al. (2015); EC (2016c); EC et al. (2012).

\begin{tabular}{|c|c|c|}
\hline Indicator & Unit & Recent progress \\
\hline \multicolumn{3}{|l|}{ Energy use } \\
\hline Energy intensity & $\begin{array}{l}\text { Gross inland consumption of energy divided } \\
\text { by Gross Domestic Product }\end{array}$ & Decreasing since 2006 \\
\hline Energy intensity & Gigajoules per tonne output & Decreasing \\
\hline Gross inland energy use & Million tonnes of oil equivalent (Mtoe) & $\begin{array}{l}\text { Fluctuating (decrease between } \\
2012-2014 \text {, increase in 2015) }\end{array}$ \\
\hline Energy productivity & $\begin{array}{l}\text { GDP (calculated in PPS) per gross inland } \\
\text { consumption of energy }\end{array}$ & Increasing but too slow \\
\hline Energy dependence & Net energy imports as $\%$ of total energy use & Increasing since 2001 \\
\hline \multicolumn{3}{|l|}{ Material use } \\
\hline Resource productivity & GDP per Raw Material Consumption & Increasing since 2000 \\
\hline Resource use per capita & $\begin{array}{l}\text { Domestic material consumption per popula- } \\
\text { tion }\end{array}$ & $\begin{array}{l}\text { Decreasing since } 2008 \text { but } \\
\text { progress too slow }\end{array}$ \\
\hline Material costs & Percentage of gross production value & High \\
\hline Metal prices & Euros & $13 \%$ increase between $2010-2020$ \\
\hline \multicolumn{3}{|l|}{ Waste } \\
\hline $\begin{array}{l}\text { Generation of waste ex- } \\
\text { cluding major minerals }\end{array}$ & Waste generation (kg/capita/year) & $\begin{array}{l}\text { Decreasing since } 2004 \text { but } \\
\text { progress too slow }\end{array}$ \\
\hline $\begin{array}{l}\text { Landfill rate of waste ex- } \\
\text { cluding major minerals }\end{array}$ & Percentage of waste sent to landfill & Decreasing since 2010 \\
\hline $\begin{array}{l}\text { End-of-life recycling in- } \\
\text { put rates (EOL-RIR) }\end{array}$ & $\begin{array}{l}\text { Percentage of end-of-life mass input versus } \\
\text { total mass input }\end{array}$ & $\begin{array}{l}\text { No trend available but currently } \\
\text { low }\end{array}$ \\
\hline \multicolumn{3}{|l|}{ Environmental impacts } \\
\hline Product footprint & $\begin{array}{l}\text { Impact per function unit (e.g. } \mathrm{kgCO} 2 / \mathrm{kg} \\
\text { product output) }\end{array}$ & Progress over time not found \\
\hline Organisation footprint & Impact per function unit & Progress over time not found \\
\hline
\end{tabular}




\section{B Supplementary Material}

\section{B.1 Understanding the European Union}

In Europe, political agendas exist at multiple levels, such as that of individual Member States (MSs) or of the EU. In the area of energy and environmental matters, the EU has had legislative authority since the European Single Act was enforced in 1987. The environment was made an official EU policy area in 1993 as part of the Treaty of Maastricht, with its relevance strengthened fifteen years later through the Treaty of Lisbon (in 2009), where mitigating climate change became an official goal. In parallel to this, the development of a common EU energy policy began in 2005 with the development of the Action Plan on Energy Efficiency. This was adopted a year later, in 2006, after the publication of a Green paper on "A European strategy for sustainable, competitive and secure energy" . It therefore makes sense to establish the remit of this analysis at the EU level rather than at that of individual Member States (MSs).

\section{B.1.1 How does the EU's legislative process work?}

Legislation in the EU can be issued in three forms, namely through directives, decisions or regulations. In directives, the aim is to lay out 'policy principles', in which case the results are binding, but the implementation into national law is left for MSs to decide. In regulations, both the results and the implementation are defined and must be applied to all MSs. Decisions, like regulations, are also entirely binding. However, these are often targeted at specific actors or sectors, rather than to entire MSs.

\section{B.1.2 The ordinary legislative procedure}

In the EU, the Commission has the legislative initiative, that is, it is the only body that can "formally propose laws" . However, the European Parliament hereafter: the Parliament) and the European Council (hereafter: the Council) have the right to request that the Commission submit a proposal. The Parliament then decides whether to adopt it or amend it. During this first reading, the Council can decide to accept the position adopted by Parliament, in which case the proposed legislation is adopted, or it can decide to amend this and return the proposal back to Parliament for a second reading. If amendments are requested, then the Parliament has three options, it can: (1) approve the Councils position, in which case the act is approved; (2) propose amendments, in which case the proposal is returned for a second reading in the Council; (3) reject it, in which case the procedure terminates. If the proposal is returned to Council for a second reading, this must decide whether to approve the proposed amendments, in which case the legislation is adopted, or to reject these, triggering the convening of the Conciliation Committee. In the Parliament's website, it is noted that "the vast majority of European laws are adopted jointly by the European Parliament and the Council". 


\section{B.1.3 The origins of legislation}

Although the Commission is the sole initiator of legislation, Nugent (2001) Nugent and Rhinard (2001) explains that they do not "act wholly on the basis of [their] own ideas and preferences" and that the indeed the "origins of EU legislation are many and varied". The author names four main origins of legislation: (1) the need to honour treaties or obligations; (2) the need to adjust or develop existing legislation; (3) the official requests made by the Parliament, the European Council, the Council of Ministers or other European committees; (4) the unofficial requests made by influential interest groups. Within these, the need to adjust or develop existing legislation, referred to as policy inheritance hereafter, is identified as the most common reason behind the proposal of legislation.

\section{B.1.4 The functioning of Commission}

In investigating why ME never made it into the energy policy agenda, it is key to understand the structure in which policy-making is operationalised. The Commission is divided into a political (College of Commissioners) and an administrative (services) branch, both of which are headed by the Commission President and Vice-Presidents. The College of Commissioners is the collective "responsible for the decisions and actions taken in the name of the Commission" . This is composed of 28 members, one from each MS, including the President and Vice-Presidents. Each Commissioner is given responsibility for a specific policy area. To operationalise the policy-making process, the Commission has the administrative branch, i.e. the services. These are organised into departments, most of which are denoted Directorate Generals (DGs). DGs are supported by other departments, denoted as 'services' and executive agencies. DGs are then further divided into Directorates, each of which is headed by 'directors'. In turn, each Directorate is composed of units headed by 'heads of unit'.

At the time of writing (October 2017), there are 33 DGs, 16 service departments and 6 executive agencies. The three most relevant DGs to this study are DG ENERGY, DG ENVIRONMENT and DG CLIMA. DG ENERGY is organised into 5 Directorates, which consist of 17 individual units. Within this, there is one unit specifically tasked with Energy efficiency, under Directorate C. DG ENVIRONMENT is organised into 6 Directorates, divided into 24 thematic units. Within this, there are two units relevant to this work, the units tasked with: (1) 'circular economy and green growth'; and (2) Implementation \& Support to Member States, under which environmental assessments are developed. DG CLIMA is organised into 4 Directorates (one of which is shared with DG ENVIRONMENT), and 17 units. Within the Commission, the DGs are the entities directly responsible for preparing legislative proposals. A lead DG is assigned to each proposal according to its policy remit. In the case of a dispute between two DGs over the leadership of a policy proposal, the Secretariat General comes into action. This is an entity within the Commission, which is tasked with ensuring the general coherence of the Commission's work. 
Table B.1 summarises the key MSF studies for the EU. 


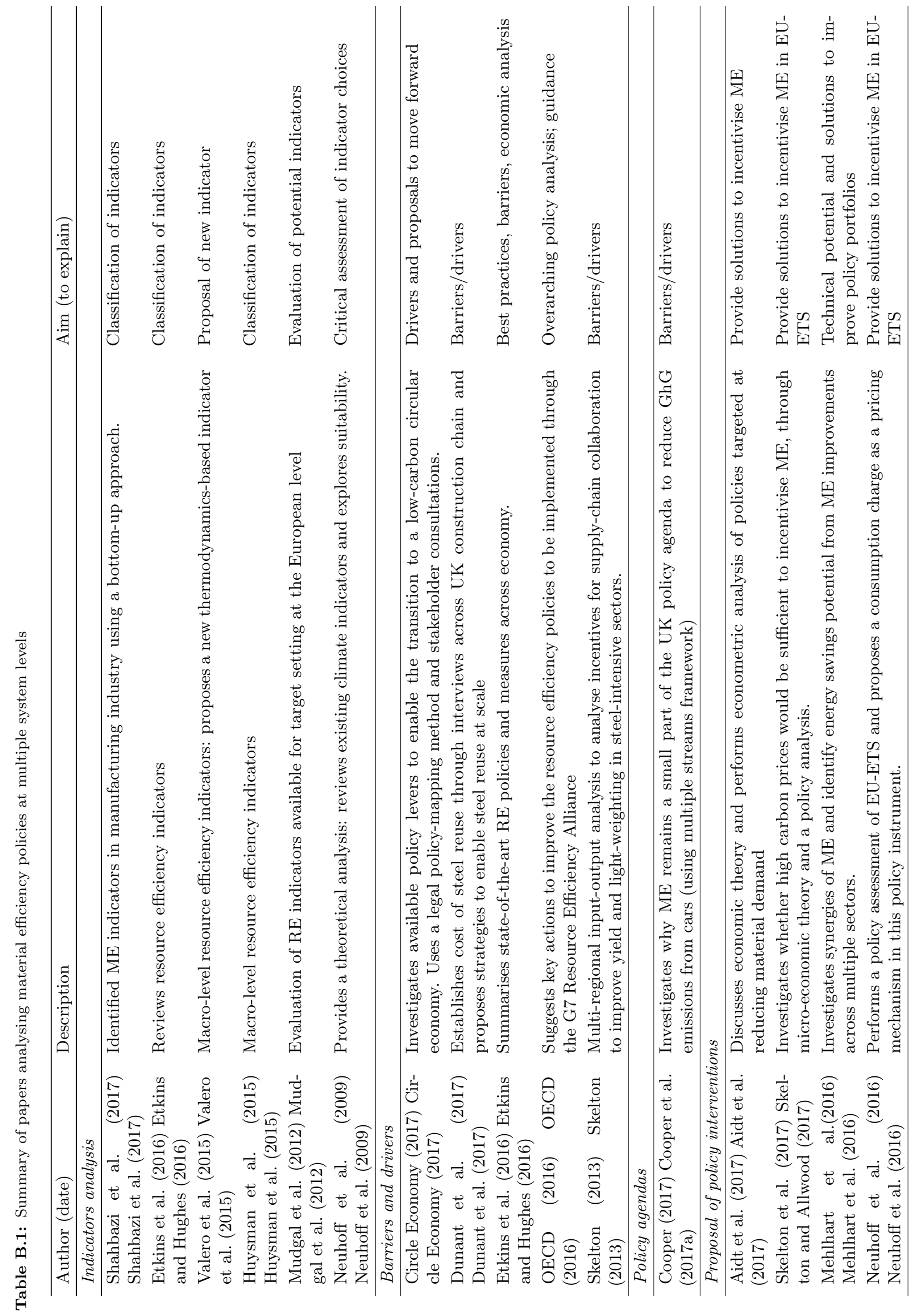




\section{B.2 Adaptions to MSF}

...give more details about how this was adapted from previous studies?

Table B.2: Classification of ME measures

\begin{tabular}{llll}
\hline Material efficiency & (production) & Material sufficiency & (consumption) \\
\hline Waste reduction & $\begin{array}{l}\text { Reduced waste during processing re- } \\
\text { duces material requirements }\end{array}$ & $\begin{array}{l}\text { Extended product } \\
\text { lifetime }\end{array}$ & $\begin{array}{l}\text { Design and maintenance of } \\
\text { longer lasting products }\end{array}$ \\
Recycling & $\begin{array}{l}\text { Increased recycling reduces deple- } \\
\text { tion of natural reserves and in- } \\
\text { creases energy consumption }\end{array}$ & $\begin{array}{l}\text { Shift from goods } \\
\text { to services }\end{array}$ & $\begin{array}{l}\text { Reduce requirements for } \\
\text { individual ownership }\end{array}$ \\
Light-weighting & $\begin{array}{l}\text { Reduced material inputs through } \\
\text { the design of lighter products }\end{array}$ & & \\
$\begin{array}{l}\text { Material/product } \\
\text { substitution }\end{array}$ & $\begin{array}{l}\text { Substitution of high-carbon inten- } \\
\text { sive materials with low-carbon ones }\end{array}$ & $\begin{array}{l}\text { Lifetime optimisa- } \\
\text { tion }\end{array}$ & $\begin{array}{l}\text { Change behaviour so that } \\
\text { products are used for full, } \\
\text { optimised lifetime }\end{array}$ \\
Synergies & By-product use across sectors & & \\
\hline
\end{tabular}


Table B.3: Summary of EU-funded projects related to ME in industry

\begin{tabular}{|c|c|c|c|}
\hline Project title & Start/End & Sector & Aspect of ME studied \\
\hline $\begin{array}{l}\text { MORE (Monitoring Resource Effi- } \\
\text { ciency) }\end{array}$ & $2015-17$ & $\begin{array}{l}\text { Chemicals/ petro- } \\
\text { chemicals industries }\end{array}$ & $\begin{array}{l}\text { Recycling, reduction of yield } \\
\text { loss and raw material inputs }\end{array}$ \\
\hline $\begin{array}{l}\text { ENLIGHT (Enhanced Lightweight De- } \\
\text { sign) }\end{array}$ & $2012-14$ & $\begin{array}{l}\text { Automotive sector } \\
\text { electric vehicles) }\end{array}$ & Light-weighting \\
\hline $\begin{array}{l}\text { SuPLight (Sustainable and efficient } \\
\text { Production of Lightweight solutions) }\end{array}$ & $2011-14$ & $\begin{array}{l}\text { Automotive sector (fo- } \\
\text { cus on aluminium) }\end{array}$ & $\begin{array}{l}\text { Re-using, recycling and light- } \\
\text { weighting }\end{array}$ \\
\hline $\begin{array}{l}\text { DESIRE (Development of a System } \\
\text { of Indicators for a Resource efficient } \\
\text { Europe) }\end{array}$ & $2012-16$ & $\begin{array}{l}\text { National, EU and } \\
\text { global, industry and } \\
\text { product group level }\end{array}$ & $\begin{array}{l}\text { Resource use indicator devel- } \\
\text { opment }\end{array}$ \\
\hline $\begin{array}{l}\text { CRM_INNONET (Critical Raw Mate- } \\
\text { rials Innovation Network) }\end{array}$ & 2007 & Industry & $\begin{array}{l}\text { Material, product, service, } \\
\text { process substitution }\end{array}$ \\
\hline $\begin{array}{l}\text { ZEROWIN (Towards Zero Waste in } \\
\text { Industrial Networks) }\end{array}$ & $2009-14$ & $\begin{array}{l}\text { Automotive, photo- } \\
\text { voltaic, construction/ } \\
\text { demolition sectors }\end{array}$ & $\begin{array}{l}\text { Waste prevention (re-use and } \\
\text { recycling), industrial symbio- } \\
\text { sis }\end{array}$ \\
\hline $\begin{array}{l}\text { REECOVER (Recovery of Rare Earth } \\
\text { Elements) }\end{array}$ & $2014-17$ & $\begin{array}{l}\text { Raw material sector } \\
\text { (WEEE recycling and } \\
\text { iron ore industries) }\end{array}$ & Recycling \\
\hline $\begin{array}{l}\text { TOP-REF (Tools for monitoring and } \\
\text { assessing Resource-efficiency in the } \\
\text { value Chain or Process Industry) }\end{array}$ & $2014-17$ & $\begin{array}{l}\text { Energy-intensive } \\
\text { industries }\end{array}$ & $\begin{array}{l}\text { Recycling, reduction of yield } \\
\text { loss and raw material inputs }\end{array}$ \\
\hline $\begin{array}{l}\text { COCOP (Coordinating Optimisation } \\
\text { of Complex Industrial Processes) }\end{array}$ & $2016-$ & $\begin{array}{l}\text { Copper and steel in- } \\
\text { dustries }\end{array}$ & $\begin{array}{l}\text { Plant-wide optimisation (ma- } \\
\text { terial use reduction) }\end{array}$ \\
\hline $\begin{array}{l}\text { CoPro (Improved energy and resource } \\
\text { efficiency by better coordination of } \\
\text { production in the process industries) }\end{array}$ & $2016-20$ & $\begin{array}{l}\text { Chemicals and petro- } \\
\text { chemicals industries }\end{array}$ & $\begin{array}{l}\text { Plant-wide optimisation (ma- } \\
\text { terial use reduction) }\end{array}$ \\
\hline RESLAG (Turning waste into value) & $2015-19$ & Steel industry & $\begin{array}{l}\text { Reduction of material by- } \\
\text { product loss }\end{array}$ \\
\hline $\begin{array}{l}\text { FISSAC (Fostering Industrial Symbio- } \\
\text { sis for a Sustainable Resource Inten- } \\
\text { sive Industry across the extended Con- } \\
\text { struction Value Chain) }\end{array}$ & $2015-20$ & $\begin{array}{l}\text { Construction value } \\
\text { chain }\end{array}$ & $\begin{array}{l}\text { Waste prevention, industrial } \\
\text { symbiosis }\end{array}$ \\
\hline $\begin{array}{l}\text { EPOS (Enhanced energy and resource } \\
\text { Efficiency and Performance in process } \\
\text { industry Operations via onsite and } \\
\text { cross-sectorial Symbiosis) }\end{array}$ & $2015-20$ & $\begin{array}{l}\text { Energy-intensive } \\
\text { industries }\end{array}$ & Industrial symbiosis \\
\hline
\end{tabular}

\section{References}

Robert Ackrill and Adrian Kay. Multiple streams in EU policy-making: the case of the 2005 sugar reform. Journal of European Public Policy, 18:72-89, 2011. doi: 10.1080/13501763. 2011.520879 .

Robert Ackrill, Adrian Kay, and Nikolaos Zahariadis. Ambiguity, Multiple Streams, and EU Policy. Journal of European Public Policy, 20, 2013. doi: 10.1080/13501763.2013.781824.

Toke Aidt, Lili Jia, and Hamish Low. Are prices enough? The economics of material demand reduction. Philosophical Transactions of the Royal Society A: Mathematical, Physical and Engineering Sciences, 375, 2017. 
Julian Allwood and Jonathan Cullen. Sustainable Materials: With both eyes open. 2012.

Julian M Allwood and Alexandra C H Skelton. Industrial metamorphosis :A response to the green paper on Building our Industrial Strategy. University of Cambridge, 2017.

Julian M. Allwood, Jonathan M. Cullen, and Rachel L. Milford. Options for achieving a $50 \%$ cut in industrial carbon emissions by 2050. Environmental Science and Technology, 44(6): 1888-1894, 2010. doi: 10.1021/es902909k.

Julian M. Allwood, Michael F. Ashby, Timothy G. Gutowski, and Ernst Worrell. Material efficiency: A white paper. Resources, Conservation and Recycling, 55(3):362-381, 2011. doi: http://dx.doi.org/10.1016/j.resconrec.2010.11.002.

B Axford. Macro-lite: Ways to Understand Europe-Making in the Global Era. Journal of Contemporary European Studies, 23(2):176-192, 2015. doi: 10.1080/14782804.2015.1029248.

Ian Bache. Measuring quality of life for public policy : an idea whose time has come? Agenda-setting dynamics in the European Union Measuring. Journal of European Public Policy, pages 37-41, 2013.

Frank Baumgartner, Bryan D Jones, and J D Wilkerson. Studying policy dynamics. In Policy Dynamics, chapter 2, pages 29-46. Chicago University Press, 2002.

S Borrás and C.M. Radaelli. The politics of governance architecture: creation, change and effects of the EU Lisbon Strategy. Journal of European Public Policy, 18(4):463-84, 2011.

Emanuela Bozzini. Pesticide Policy and Politics in the European Union: regulatory assessment, implementation and enforcement. Springer, 2017.

Steffen Brunner. Understanding policy change: Multiple streams and emissions trading in Germany. Global Environmental Change, 18(3):501-507, 2008. doi: https://doi.org/10. 1016/j.gloenvcha.2008.05.003.

Paul Cairney. A Multiple Lenses' Approach to Policy Change: the Case of Tobacco Policy in the UK. British Politics, 2, 2007.

Paul Cairney and Michael D Jones. Kingdon's Multiple Streams Approach : What Is the Empirical Impact of this Universal Theory? Journal of European Public Policy, 44:37-58, 2016.

Circle Economy. Policy levers for a low-carbon circular economy. 2017.

Paul Cloke, Ian Cook, Philip Crang, Mark Goodwin, Joe Painter, and Chris Philo. Talking to People. In Practising human geography. SAGE Publications, 2004.

Ross J.K. Cobb, R.W. Agenda building as a comparative political process. American Political Science Review, 70:126-38, 1976. 
Samuel J G Cooper, Jannik Giesekam, Geoffrey P Hammond, Jonathan B Norman, Anne Owen, John G Rogers, and Kate Scott. Thermodynamic insights and assessment of the circular economy'. Journal of Cleaner Production, 162:1356-1367, 2017a.

Samuel J G Cooper, Jannik Giesekam, Geoffrey P Hammond, Jonathan B Norman, Anne Owen, John G Rogers, and Kate Scott. Thermodynamic insights and assessment of the circular economy'. Journal of Cleaner Production, 162:1356-1367, 2017b.

Simone Cooper-Searle, Finbarr Livesey, and Julian M Allwood. Why are Material Efficiency Solutions a Limited Part of the Climate Policy Agenda? An application of the Multiple Streams Framework to UK policy on CO2 emissions from cars. Environmental Policy and Governance, pages n/a-n/a, 2017. doi: 10.1002/eet.1782.

Paul Copeland and Scott James. Policy windows, ambiguity and Commission entrepreneurship : explaining the relaunch of the European Union's economic reform agenda. Journal of European Public Policy, 1763:0-19, 2014. doi: 10.1080/13501763.2013.800789.

Jonathan M Cullen and Julian M Allwood. Mapping the Global Flow of Aluminum : From Liquid Aluminum to End-Use Goods. Environmental Science 85 Technology, 47:3057-3064, 2013.

Jonathan M Cullen, Julian M Allwood, and Margarita D Bambach. Mapping the Global Flow of Steel : From Steelmaking to End-Use Goods. Environmental Science 83 Technology, 46(13048-13055), 2012.

Directorate-General for Energy. Public Consultation for the Review of Directive 2012 / 27 / EU on Energy Efficiency. 2016. URL https://ec.europa.eu/energy/sites/ener/ files/documents/PublicConsultationReportontheEEDReview.pdf.

Cyrille F Dunant, Michal Piotr Drewniok, Simon Corbey, Jonathan M Cullen, Cyrille F Dunant, P Drewniok, Michael Sansom, Simon Corbey, and Julian M Allwood. Real and perceived barriers to steel reuse across the UK construction value chain. Resources, Conservation \& Recycling, 126, 2017. doi: 10.1016/j.resconrec.2017.07.036.

EC. Communication from the Commission Action Plan for Energy Efficiency: Realising the Potential. page $\operatorname{COM}(2006) 545$ final, 2006.

EC. Communication from the Commission to the European Parliament, the Council, the European Economic and Social Committee and the Committee of the Regions: Sustainable Consumption and Production and Sustainable Industrial Policy Action Plan. 2008a. URL http://eur-lex.europa.eu/legal-content/EN/TXT/PDF/?uri= CELEX : 52008DC0397\{\&\}from=EN.

EC. Communication from the Commission to the European Parliament, the Council, the European economic and social Committee and the Committee of the Regions - 2020 by 2020 - Europe's climate change opportunity. COM (2008) 30 final, page Brussels, 2008b. 
EC. The raw materials initiative meeting our critical needs for growth and jobs in Europe. Communication from the Commission to the European Parliament and Council, SEC(2008), 2008c.

EC. Directive 2009/29/EC of the European Parliament and of the Council of 23 April 2009. Official Journal of the European Union, 140:63-87, 2009a. doi: 10.3000/17252555.L_2009. 140.eng.

EC. Directive 2010/75/EU Industrial Emissions. Official Journal of the European Union, pages 17-119, 2009b. doi: 10.3000/17252555.L_2010.334.eng.

EC. Communication from the Commission to the European Parliament, the Council, the European Economic and Social Committee and the Committee of the Regions on Roadmap to a Resource Efficient Europe. 2011a.

EC. Communication from the Commission to the European Parliament, the Council, the European Economic and Social Committee and the Committee of the Regions: Energy Efficiency Plan. page COM(2011) 109 final, 2011b.

EC. Minutes of the 1985th meeting of the Commission held in Brussels (Berlaymont) on Wednesday 11 January 2012 . PV(2012) 1985 final, 25 January, 2012. doi: 10.1093/ oxfordhb/9780199546282.013.0024.

EC. Commission Staff Working Document, Guide for National Energy Efficiency Action Plans Accompanying the document establishing a template for National Energy Efficiency Action Plans under Directive 2012/27/EU of the European Parliament and the Council. pages 1-45, 2013.

EC. Communication from the Commission to the European Parliament, the Council, the European Economic and Social Committee and the Committee of the Regions: A policy framework for climate and energy in the period from 2020 to 2030. 2014a.

EC. Report of the public consultation on the review of progress on the 2020 energy efficiency objective. 2014b. URL https://ec.europa.eu/energy/en/consultations/ consultation-progress-towards-2020-energy-efficiency-objective-and-2030-energy.

EC. Communication from the commissions to the European Parliament, the Council, the European Economic and Social Committee and the Committee of the Regions Towards a circular economy: a zero waste programme for Europe. 2014c.

EC. Communication from the Commission to the European Parliament and the Council: Energy Efficiency and its contribution to energy security and the 2030 Framework for climate and energy policy. 2014d.

EC. Proposal for a Directive of the European Parliament and of the Council amending Directive 2003/87/EC to enhance cost-effective emission reductions and low-carbon investments. $2015 \mathrm{a}$. 
EC. Communication from the Commission to the European Parliament, the Council, the European Economic and Social Committee and the Committee of the Regions: Closing the loop - An EU action plan for the Circular Economy. 2015b.

EC. Communication from the Commission to the European Parliament, the Council, the European Economic and Social Committee and the Committee of the Regions: Digitising European Industry Reaping the full benefits of a Digital Single Market. COM(2016) 180 final, 2016a.

EC. Putting energy efficiency first: consuming better, getting cleaner, $2016 \mathrm{~b}$.

EC. Raw Materials Scoreboard. 2016c. doi: 10.2873/28674.

EC. Minutes of the 2220th meeting of the Commission held in Brussels (Berlaymont) on Wednesday 12 July 2017 . PV(2017) 2220 final, 6 Septembe, 2017a.

EC. Register of Commission Documents: Commission meetings, 2017b. URL http://ec . europa.eu/transparency/regdoc/?fuseaction=gridyear.

EC, Joint Research Centre (JRC), and Institute for Environment and Sustainability (IES). Product Environmental Footprint (PEF) Guide. 2012. URL http://ec.europa.eu/ environment/eussd/pdf/footprint/PEFmethodologyfinaldraft.pdf.

EEA. The European Environment: State and Outlook 2010. 2010.

EEA. Circular economy in Europe: Developing the knowledge base. 2016. ISBN 9789292137199.

EPA. Resource efficiency in industries - via conclusions on Best Available Techniques (BAT) under Industrial Emissions Directive. Ministry of Environment and Food of Denmark, 2016.

Paul Etkins and Nick Hughes. Resource Efficiency: Potential and Economic implications. UNESCO, UNEP, 2016. ISBN 9789280736458.

Paul Etkins and Nick Hughes. Resource Efficiency: Potential and Economic implications. UNESCO, UNEP, 2017. ISBN 9789280736458.

Eurostat. Smarter, greener, more inclusive? Indicators to support the Europe 2020 strategy. Technical report, Publications Office of the European Union, 2017.

Eurostat. Final energy consumption by sector, 2018. URL http://ec.europa.eu/eurostat/ web/products-datasets/-/tsdpc320.

F5 Networks. F5 Software, 2017. URL https://f5.com.

M. Fischedick, J. Roy, A. Abdel-Aziz, A. Acquaye, J. M. Allwood, J.-P. Ceron, Y. Geng, H. Kheshgi, A. Lanza, D. Perczyk, L. Price, E. Santalla, C. Sheinbaum, and K. Tanaka. Climate Change 2014: Mitigation of Climate Change. pages 739-810, 2014. 
Doris Fuchs. Windows of Opportunity for Whom ? Commissioners, Access, and the Balance of Interest in European Environmental Governance. Social Sciences, 6, 2017. doi: 10.3390/socsci6030073.

G7 Resource Efficiency Alliance. Toyama Framework on Material Cycles. Technical report, 2016.

Herbert Gottweis. Rhetoric in Policy Making: Between Logos, Ethos, and Pathos. In Frank Fischer, J.G. Miller, and Mara S. Sidney, editors, Handbook of Public Policy Analysis Theory, Politics, and Methods, chapter 17. Taylor \& Francis Group, 2007.

Paul W Griffin, Geoffrey P Hammond, and Jonathan B Norman. Opportunities for Energy Demand and Carbon Emissions Reduction in the Chemicals Sector. Energy Procedia, 105: 4347-4356, 2017.

Paul W Griffin, Geoffrey P Hammond, and Jonathan B Norman. Industrial decarbonisation of the pulp and paper sector: A UK perspective. Applied Thermal Engineering, 134:152-162, 2018.

Jean Grugel and Ingi Iusmen. The european commission as guardian angel: the challenges of agenda-setting for children's rights. 2013.

Nicole Herweg. Explaining European agenda-setting using the multiple streams framework : the case of European natural gas regulation. Policy Sciences, 49:13-33, 2016. doi: 10.1007/s11077-015-9231-z.

Barry Hindess. Rational choice theory and the analysis of political action. Economy and Society, 13(3):256-277, 1984. doi: 10.1080/03085148400000009.

J.D. Huber and C.R. Shipan. Deliberate Discretion: The Institutional Foundations of Bureaucratic Autonomy. New York: Cambridge University Press., 2003.

Alexandra Humphris-Bach, Chiara Essig, Gareth Morton, and Les Harding. EU Resource efficiency scoreboard. 2015.

Sofie Huysman, Serenella Sala, Lucia Mancini, Fulvio Ardente, Rodrigo a.F. Alvarenga, Steven De Meester, Fabrice Mathieux, and Jo Dewulf. Toward a systematized framework for resource efficiency indicators. Resources, Conservation and Recycling, 95:68-76, 2015.

IEA. Energy Efficiency Governance Handbook. Technical report, 2010.

IEA. Energy Efficiency Market Report. Technical report, OECD/IEA, 2013.

IEA. World Energy Outlook. 2015.

Raili Kajaste and Markku Hurme. Cement industry greenhouse gas emissions management options and abatement cost. Journal of Cleaner Production, 112:4041-4052, 2016. 
Christian Kaunert and Marina Della Giovanna. Post-9/11 EU counter-terrorist financing cooperation: differentiating supranational policy entrepreneurship by the Commission and the Council Secretariat. European Security, 19(2):275-295, 2010. doi: 10.1080/09662839. 2010.507246 .

John W Kingdon. Agendas, Alternatives, and Public Policies. Little brown and company, 1984.

John W Kingdon. Agendas, Alternatives, and Public Policies. Longman Classic in Political Science, second edition, 2003.

Heike Klüver. Lobbying in the European Union: Interest Groups, Lobbying Coalitions, and Policy Change. Oxford Scholarship Online, 2013. ISBN 9780199657445.

Charles E Lindblom. The Science of "Muddling Through". Public Administration Review, 19 (2):79-88, 1959. doi: 10.2307/973677. URL http://www.jstor.org/stable/973677.

E Lombardo and M Forest. The europeanization of gender equality policies: A discursivesociological approach. Comparative European Politics, 13(2):222-239, 2015. doi: 10.1057/ cep.2013.18.

R Longhurst. Semi-structured interviews and focus groups. In Key methods in geography, chapter 9. SAGE Publications, 2010.

James Mahoney. Path Dependence in Historical Sociology. Theory and Society, 29(4):507-548, 2000

Tomas Maltby. European Union energy policy integration : A case of European Commission policy entrepreneurship and increasing supranationalism. Energy Policy, 55:435-444, 2013. doi: 10.1016/j.enpol.2012.12.031.

H Meadwell. Institutions and Political Rationality. In A. Lecours, editor, New Institutionalism, Theory and Analysis, pages 1-32. University of Toronto Press, 2005. ISBN 9781442677630. URL http://francais.mcgill.ca/files/politicalscience/ meadwelldraftinstitutions.pdf.

G Mehlhart, I Bakas, M Herczeg, P Strosser, C Rynikiewicz, A Agenais, T Bergmann, M Mottschall, F Antony, V Bilsen, S Greeven, P Debergh, and D Hay. Study on the Energy Saving Potential of Increasing Resource Efficiency Final Report. 2016. doi: 10.2779/17222.

Rachel L Milford, Stefan Pauliuk, Julian M Allwood, and Daniel B Müller. The Roles of Energy and Material Efficiency in Meeting Steel Industry CO2 Targets. Environmental Science \& Technology, 47(7):3455-3462, apr 2013. ISSN 0013-936X. doi: 10.1021/es3031424.

Shailendra Mudgal, Adrian Tan, Sarah Lockwood, Nina Eisenmenger, Marina FischerKowalski, Stefan Giljum, and Martin Brucker. Assessment of resource efficiency indicators and targets. 2012. URL http://ec.europa.eu/environment/enveco/ resource\{_\}efficiency/pdf/report.pdf. 
Karsten Neuhoff, Simone Cooper, Tima Laing, Sarah Lester, and Adam Rysanek. Indicator Choices and Tradeoffs: Facilitating the success of international climate policies and projects. pages 1-42, 2009.

Karsten Neuhoff, Roland Ismer, Carolyn Fischer, Yong-gun Kim, Jan Stede, Lars Zetterberg, and Vera Zipperer. Inclusion of Consumption of carbon intensive materials in emissions trading An option for carbon pricing post-2020. 2016.

A S Norgaard. Rediscovering reasonable rationality in institutional analysis. European Journal of Political Research, 29(1):31-57, 1996. doi: 10.1111/j.1475-6765.1996.tb00640.x.

Tobias Nowak. Of Garbage Cans and Rulings: Judgments of the European Court of Justice in the EU Legislative Process. West European Politics, 33(4):753-769, 2010. doi: 10.1080/01402381003794605.

Neil Nugent and Mark Rhinard. The European Commission. Palgrave, 2001.

OECD. Policy Guidance on Resource Efficiency. 2016.

Elinor Ostrom. Rational Choice Theory and Institutional Analysis: Toward Complementarity. The American Political Science Review, 85, 1991.

Stefan Pauliuk and Daniel B Müller. The role of in-use stocks in the social metabolism and in climate change mitigation. Global Environmental Change, 24:132-142, 2014. doi: https://doi.org/10.1016/j.gloenvcha.2013.11.006.

M J Pedersen. Real-world Europeanisation: the silent turning of small gears*. Policy Studies, 38(1):91-107, 2017. doi: 10.1080/01442872.2016.1192114.

Mark A Pollack. Handbook of European Union Politics, 2006. URL http://sk. sagepub. com/reference/hdbk\{_\}eurounion.

Sebastiaan Princen. Agenda-setting in the European Union. Palgrave Macmillan, 2009.

Sebastiaan Princen and Mark Rhinard. Crashing and creeping: agenda-setting dynamics in the European Union. Journal of European Public Policy, 13(7):1119-1132, 2006. doi: $10.1080 / 13501760600924233$.

Julia Reinaud and Amelie Goldberg. Ten Key Messages for Effective Policy Packages Sharing best practices in industrial energy. 2011.

Jeremey Richardson. Policy-making in the EU Interests, ideas and garbage cans of primeval soup. In European Union: power and policy-making. Routledge, 2001.

Paul A. Sabatier, Nikolaos Zahariadis, James L True, Bryan D Jones, and Frank Baumgartner. Theories of the Policy Process. Westview Press, 1999. ISBN 0-8133-9986-6. 
Kate Scott, Katy Roelich, Anne Owen, and John Barrett. Extending European energy efficiency standards to include material use: an analysis. Climate Policy, pages 1-15, jul 2017. doi: 10.1080/14693062.2017.1333949.

Sasha Shahbazi, Mohammed Salloum, Martin Kurdve, and Magnus Wiktorsson. Material efficiency measurement: empirical investigation of manufacturing industry. Procedia Manufacturing, 8(October 2016):112-120, 2017. doi: 10.1016/j.promfg.2017.02.014.

Alexandra C H Skelton. The Motivations for Material Efficiency : incentives and trade-offs along the. Doctor of philosophy, University of Cambridge, 2013.

Alexandra C H Skelton and Julian M Allwood. The carbon price: a toothless tool for material efficiency? Philosophical Transactions of the Royal Society A: Mathematical, Physical and Engineering Sciences, 375, 2017.

Joe Smith. Demanding stories: television coverage of sustainability, climate change and material demand. Philosophical Transactions of the Royal Society A: Mathematical, Physical and Engineering Sciences, 375(2095):20160375, 2017. doi: 10.1098/rsta.2016.0375.

SPIRE. SPIRE (Sustainable Process Industry through Resource and Energy Efficiency), 2017. URL https://www.spire2030.eu/intro.

Alicia Valero, Antonio Valero, and Guiomar Calvo. Using thermodynamics to improve the resource efficiency indicator GDP/DMC. Resources, Conservation \& Recycling, 94:110-117, 2015. doi: 10.1016/j.resconrec.2014.12.001.

Stijn Van Ewijk, Julia A. Stegemann, and Paul Ekins. Global Life Cycle Paper Flows, Recycling Metrics, and Material Efficiency. Journal of Industrial Ecology, 00(0):1-8, 2017. ISSN 15309290. doi: 10.1111/jiec.12613.

Nikolaos Zahariadis. Ambiguity and choice in European public policy. Journal of European Public Policy, 15(4):514-530, 2008. doi: 10.1080/13501760801996717. 